Keshar M. Ghimire*

\title{
Supply of immigrant entrepreneurs and native entrepreneurship
}

\begin{abstract}
Using nationally representative data from the United States, the author estimates the causal impact of immigrant entrepreneurship on entrepreneurial propensities of natives. The author draws data from the Annual Social and Economic Supplement of the Current Population Survey and uses within-state variation in supply of immigrant entrepreneurs for identification. To address concerns of endogeneity in the supply of immigrant entrepreneurs, the author takes advantage of a quasi-experiment provided by the State Children's Health Insurance Program. While the Ordinary Least Squares estimates indicate a positive effect, the Two Stage Least Squares estimates suggest that, on average, there is no significant effect of immigrant entrepreneurs on native entrepreneurship. Moreover, there is no net effect on subgroups of natives separated by skill level. There is also some evidence that immigrant entrepreneurs may "crowd-in" Blacks into certain types of self-employment. These results are in contrast to the significant negative impact suggested by the previous literature.
\end{abstract}

$\begin{array}{ll}\text { Current version: } & \text { February 10,2021 } \\ \text { Keywords: } & \text { entrepreneurship, immigration, self-employment, incorporated } \\ & \text { and unincorporated businesses, State Children's Health Insurance } \\ & \text { Program } \\ \text { JEL codes: } & \text { J61, F22, L26 } \\ \text { Corresponding author: } & \text { Keshar M. Ghimire } \\ & \text { keshar.ghimire@uc.edu }\end{array}$

Business and Economics Department, University of Cincinnati - Blue Ash, Muntz 325BA, 9555 Plainfield Rd, $\mathrm{OH} 45236$, USA.

(c) The Author(s). 2021. Open Access This article is distributed under the terms of the Creative Commons Attribution 4.0 International License (http://creativecommons.org/licenses/by/4.0/), which permits unrestricted use, distribution, and reproduction in any medium, provided you give appropriate credit to the original author(s) and the source, provide a link to the Creative Commons license, and indicate if changes were made. @- Cite as: Ghimire. IZA Journal of Development and Migration (2021) 12:04 


\section{Introduction}

Immigrant entrepreneurs play an important social and economic role in economies around the world. In the United States (US), the focus of this study, immigrants lead natives not only in business creation rate but also in business ownership rate (Fairlie, 2012). Approximately $25 \%$ of all firms in the US are founded by immigrants and the share of immigrant entrepreneurs exceeds $40 \%$ in states like California and New York (Kerr and Kerr, 2020). Despite such a large proportion of immigrant workers engaging in entrepreneurial activities, the question of how immigrant entrepreneurs affect the entrepreneurial propensities of natives is not well understood. On one hand, immigrant entrepreneurs increase demand for intermediate goods and services, stimulate technological innovation (Duleep et al., 2012), aid in cross-border technology diffusion (Kerr, 2008), and facilitate international trade (Gould, 1994). These effects are likely to help in growth of native-owned businesses (Coad and Rao, 2008) and encourage more natives to take up entrepreneurship (the "crowding in" effect). On the other hand, immigrant entrepreneurs compete with the native-run businesses by cutting costs and accepting lower profits (Ackerman and Tellis, 2001; Joona, 2011), potentially displacing natives from entrepreneurial activities (the "crowding out" effect). The opposing forces make the net impact of immigrant entrepreneurs on native entrepreneurial propensities theoretically ambiguous. This paper provides the first quasi-experimental evidence for the net impact of immigrant entrepreneurs on entrepreneurial propensities of natives.

The impact of immigrant entrepreneurs on native entrepreneurial propensities has several policy implications. Entrepreneurship is a significant component of economic growth (Van Stel et al., 2005; Haltiwanger et al., 2013; Rupasingha and Goetz, 2013). In the US alone, 28 million small businesses account for $54 \%$ of nationwide sales and provide $55 \%$ of all jobs (Small Business Administration). Entrepreneurship is also a path out of poverty for many small business owners (Bruton et al., 2013). Due to these socio-economic benefits, governments at the federal, state, and local level provide tax breaks, subsidies, and other incentives to promote entrepreneurship (Rupasingha and Goetz, 2013). Moreover, many nonprofit foundations invest generously in entrepreneurial development (Goetz et al., 2010). If immigrant entrepreneurs have a net positive effect on the entrepreneurial propensities of natives, a potential policy response would be to encourage further entrepreneurship among immigrants, for example by improving their access to credit or by issuing more entrepreneurship visas. ${ }^{1}$ On the contrary, if immigrant entrepreneurs crowd out native entrepreneurs, the appropriate policy response hinges on the quality of the businesses immigrants create. ${ }^{2}$

Previous literature on immigration and entrepreneurship is limited to describing immigrant entrepreneurship (Kerr \& Kerr, 2016; Kahn et al., 2017; Kerr \& Kerr, 2020; Azoulay et al., 2020) and evaluating the impact of overall immigration on aggregate levels of entrepreneurship

1 Many immigrant receiving countries have implemented immigration policies that provide preferential treatment to potential business owners. While Canada, Australia, and the United Kingdom explicitly provide special visas by the name of "start up visa," "entrepreneur visa," and "business talent visa," respectively, the US provides "green card through investment" and also has provision to allow permanent residence to potential entrepreneurs under categories like "national interest waiver" and "exceptional ability in business."

2 For example, if immigrants create high quality businesses that make a net positive contribution to the economy even after accounting for potential losses due to crowding out, it may still be beneficial to promote entrepreneurship among the immigrants. However if immigrant-owned businesses are not necessarily better than those they displace, then steps to promote entrepreneurship among the immigrants or to attract immigrant entrepreneurs from abroad would be unwarranted. 
(Fairlie and Meyer, 1997, 2003; Unel, 2018). ${ }^{3}$ This paper extends the literature by estimating the direct causal impact of an exogenous change in the number of immigrant entrepreneurs on native entrepreneurial propensities. Specifically, I use data from the Annual Social and Economic Supplement (ASEC) of Current Population Survey (CPS) - a nationally representative survey of households in the US - to study how within-state variation in the supply of immigrant entrepreneurs affects the entrepreneurial propensities of natives. Econometrically, I model entrepreneurial propensity of natives as a function of the supply of immigrant entrepreneurs at the state level and other determinants of entrepreneurial tendency. An obvious concern with this approach is that the supply of immigrant entrepreneurs within a state is endogenous. Therefore, I use an instrumental variables strategy, which is described later in the manuscript, to circumvent the endogeneity concerns.

My findings, in contrast to those implied by previous studies, suggest that comprehensively the immigrant entrepreneurs have no impact on entrepreneurial propensities of natives. The mostly null effects observed in the full sample are robust to variations in modeling techniques and sampling period. In subsample analyses, I find evidence suggesting that immigrant entrepreneurs may have a small, but positive effect on entrepreneurial propensities of Blacks. Although not all subsample analyses are equally robust and there is no evidence, what-so-ever, of crowd-out in any subgroups of natives analyzed in this study.

\section{Background}

\subsection{Related literature}

Broadly, this paper is related to the vast literature, across disciplines, on socio-economic impacts of immigration. Most previous studies, both theoretical and empirical, on the topic examine the impact of immigrant workers on wages and employment prospects of native workers. Conclusions from theoretical models in this class of studies depend on the assumptions made on the relative skill structure of immigrant workers and native workers (which ultimately determine the elasticity of substitution between the two groups) and the elasticity of capital supply (Friedberg and Hunt, 1995; Dustmann et al., 2008; Manacorda et al., 2012). For example, if capital supply is perfectly elastic and immigrant workers are perfect substitutes for native workers, immigration does not affect the wages and employment prospects of natives. However, if immigrant workers have different skill composition than native workers, there will be winners and losers among natives even with perfectly elastic capital supply.

Empirical studies on the topic are abundant (for example Card (1990), Borjas et al. (1997), Winter-Ebmer and Zweimüller (1999), Hu (2000), Borjas et al. (2011), Ottaviano and Peri (2012), Dustmann et al. (2017), and Prantl and Spitz-Oener (2020) to state only a few) but report widely varying results. Nevertheless, a general consensus is that in the long run, immigrant workers, on average, neither lower wages of native workers (Peri, 2014) nor displace them from their jobs (Constant, 2014). Increased productivity, better skill mix, and high rate of entrepreneurship among immigrants are some of the benefits of immigration highlighted in these studies. ${ }^{4}$

3 See Aliaga-Isla and Rialp (2013) for a systematic review of literature in immigrant entrepreneurship.

4 See Kerr and Kerr (2011) for a survey of recent empirical studies on the economic impacts of immigration. 
More specifically, however, this paper aligns with a smaller group of studies within the migration literature that focuses on immigrant entrepreneurship. Studies within this space are scattered across disciplines including ethnic studies, sociology, urban studies, economics, entrepreneurship, economic geography, management studies, political science, and policy studies (Rath and Kloosterman, 2000). A majority of these studies describe immigrant entrepreneurship as a form of ethnic entrepreneurship and are often concerned with identifying distinct characteristics that make certain groups of immigrants more successful entrepreneurs than others (Evans, 1989; Yoon, 1995; Mesch and Czamanski, 1997; Min and Bozorgmehr, 2000; Kahn et al., 2017). Researchers have mainly examined entrepreneurship experiences of Hispanics, Chinese, Koreans, Indians, Iranians, and Filipinos in the North America and the experiences of Polish and Turkish immigrants in Europe (Aliaga-Isla and Rialp, 2013). Altogether, these studies highlight the various forms of human capital, social capital, and cultural attributes associated with immigrant entrepreneurs. Admittedly, the scope of this line of research is steadily expanding and scholars have explored areas as varied as the institutional environment in the context of immigrant entrepreneurship (Kloosterman, 2000), role of immigrant entrepreneurship in the high-tech sector (Hart and Acs, 2011), returns to immigrant entrepreneurship (Lofstrom, 2011), motivations and obstacles to immigrant entrepreneurship (Fatoki and Patswawairi, 2012), survival and growth of immigrant-founded businesses (Kerr \& Kerr, 2016, 2020), and the role of global forces in immigrant entrepreneurship (You and Zhou, 2019). The other area of growing interest among researchers is the role of immigrants in transnational entrepreneurship (Kwak and Hiebert, 2010; Brzozowski et al., 2017). Dabić et al. (2020) provide an excellent up to date review of studies and evolving research agenda in this area. Despite large differences in terms of focus, more often than not, studies in this group discuss immigrant entrepreneurship as an important benefit of immigration, - for example, see Rath and Kloosterman (2000), Lofstrom (2002), and Peroni et al. (2016) - but credible research on how immigrant entrepreneurs affect native entrepreneurship is inadequate.

A handful of studies examine the closely related issue of how immigration affects entrepreneurship among natives. Light and Sanchez (1987), probably the earliest among them, utilize data collected from the 1980 public-use samples of U.S. Census to find that a higher percentage of foreign-born in labor force results in a higher aggregate self-employment rate. Similarly, Fairlie and Meyer (1997) use census data from 1980 and 1990 to estimate the impact of immigration on African American self-employment and find no significant effect. However, in a subsequent related study, the authors look at the impact of immigration on the self-employment propensities of the non-African American population in the US and find a small negative impact (Fairlie and Meyer, 2003). Hunt and Gauthier-Loiselle (2010) examine the impact of skilled immigration on innovation, measured by patenting behavior, in the US and find that a one percentage point increase in the share of immigrant college graduates in the population increases patents per capita by $6 \%$. Similarly, Kerr and Lincoln (2010) examine the impact of high-skilled immigrants, entering on H-1B visas, on US technology formation. The authors conclude that total innovation, which is measured by patenting and employment in science and engineering, increases with higher H-1B admission levels. Olney (2013) examines the related issue of how firms respond to immigration and find that greater influx of immigrants translates into more firms. More recently, Unel (2018) examines the effect of immigration on 
entry and exit of US born entrepreneurs and finds negative impact on entry and exit of female entrepreneurs but no impact on male entrepreneurs. Specifically, the author finds that a $10 \%$ increase in the share of immigrants in the population lowers the entry and exit rates of female entrepreneurs by 10 and 5\% respectively. Taking a theoretical approach, Unel (2019) sets up a two country model to study the effect of immigration policies and concludes that policies that accelerate the integration of immigrants to host economy reduce offshoring of labor and increase the local supply of entrepreneurs.

Although important in their own right, existing studies closely related to this study investigate the impact of immigration on post-immigration aggregate levels of entrepreneurship or the entrepreneurship rate of natives. They fall short of disentangling the impact of immigrant entrepreneurs from that of immigrants in general. Since a wave of immigration adds both self-employed and employed to the economy, the impact of immigration is a result of the economic activities of the immigrant entrepreneurs and the non-entrepreneurs. Isolating the impact of immigrant entrepreneurs from immigration not only informs the policies related to immigration and entrepreneurship development, but also improves our understanding of the determinants of entrepreneurship among natives.

\subsection{Conceptual framework}

To empirically estimate the net impact of immigrant entrepreneurs on native entrepreneurship, I build up on a conceptual framework of self-employment outlined by Borjas (1986). In this econometric setup, an individual $i$ chooses self-employment based on the difference between market wage $w_{i}$, and the expected net income from self-employment, $y_{i}$. If we define an index function $I$ such that

$$
I_{i}=y_{i}-w_{i}=C_{i} \pi+v_{i}
$$

where $C_{i}$ is the vector of socio-economic characteristics which affect $y_{i}$ and $w_{i}, v_{i}$ is the disturbance term, and $\pi$ is a parameter vector, then the individual chooses self-employment when $I_{i}>0$. The probability of an individual being self-employed is then given by

$$
P_{i}=\operatorname{Pr}\left[I_{i}>0 \mid C_{i}\right]=\operatorname{Pr}\left[v_{i}>-C_{i} \pi \mid C_{i}\right]
$$

If $v_{i}$ is distributed symmetrically, then

$$
P_{i}=\operatorname{Pr}\left[v_{i}<C_{i} \pi \mid C_{i}\right]=F\left(C_{i} \pi\right)
$$

where $F$ is the cumulative distribution function of the random variable $v_{i}$. The parameter vector $\pi$ can now be estimated in a standard regression framework by specifying the functional form of $F$ and the elements of vector $C$.

It is hard to specify, with certainty, the exact variables that go into the vector $C$ (Borjas, 1986). However the literature, discussed in the foregoing subsection, suggests that in addition to normally considered micro and macro level determinants of labor market outcomes, the supply of immigrant entrepreneurs is likely to play an important role in a native individual's choice of self-employment. Therefore, for the purpose of estimating the net impact of immigrant entrepreneurs on native entrepreneurship, I utilize a reduced form model that specifies 
the self-employment propensity of natives as a function of supply of immigrant entrepreneurs and other relevant controls. I discuss this model in detail in Section 4.

\section{Data and Variables}

The main source of data for this study is the ASEC, popularly known as the March supplement, of the CPS. I use the uniform extracts of the CPS prepared by the Center for Economic Policy Research (CEPR). ${ }^{5}$ The CPS is administered jointly by the US Census Bureau and the US Bureau of Labor Statistics (BLS) and is the primary source of labor force statistics for the US population. While the basic CPS is a monthly survey of a nationally representative sample of approximately 60,000 households, the ASEC supplement provides data from an additional questionnaire administered every March. Apart from the usual demographic and labor force data, the ASEC supplement provides a rich set of information on work experience, income, non-cash benefits, and migration. The CPS data are well suited for this study due to the availability of sizable immigrant population in them. Although the CPS does not track same individuals over the whole duration considered in this study, the repeated cross-sectional nature of the data provides opportunity to capture aggregate trends in entrepreneurship. ${ }^{6}$

The starting sample used in the current analysis includes data from 1994 to 2016. ${ }^{7}$ To ensure that inference is based on states with meaningful immigrant population size, only states where immigrants make at least $5 \%$ of the total population in the pooled sample are considered for main analysis. ${ }^{8}$ Following the literature, the sample is limited to labor force participants in non-farm households who are between the ages of 23 and 64. In total, after implementing a list-wise deletion, the pooled sample has annual observations on 1,361,196 individuals. Among them, 1,111,850 are natives and 249,346 are immigrants. ${ }^{9}$ I make additional modifications for various sub-sample analyses as described later in the manuscript.

The outcome variable of interest in this analysis is the entrepreneurial propensity of natives. It is a binary variable indicating whether a native individual is an entrepreneur. Although, past empirical studies have considered all forms of self-employment as entrepreneurship (Blanchflower and Oswald, 1998), more recent studies have highlighted the difference between the incorporated and the unincorporated self-employment in the US context (Hipple, 2010; Olds, 2016; Levine and Rubinstein, 2017). ${ }^{10}$ Therefore, I construct separate indicators for

5 The extracts are publicly available at: http://ceprdata.org/cps-uniform-data-extracts/march-cps-supplement/marchcps-data/

6 The CPS data have their own share of limitations, such as having a considerable amount of noise in identifying occupational and industry switches and providing a poor measure of annual occupational mobility (Kambourov and Manovskii, 2013). However, they have been extensively used in the analysis of the US labor market, including topics such as the impact of immigration on wages of natives, the impact of immigration on self-employment of natives, and the state of entrepreneurship in the United States (Fairlie and Meyer, 2003; Orrenius and Zavodny, 2007; Lee and Tomohara, 2008; Chassamboulli and Palivos, 2014; Levine and Rubinstein, 2017).

7 No CPS data before 1994 can be used as the question identifying immigrant status was asked starting this year.

8 Only 35 US states exceed this threshold. However in robustness check, I consider an extended sample that includes all states. Including only states where immigrants made at least five percent of population in the year 1994 does not change results.

9 All foreign-born individuals are categorized as immigrants.

10 Incorporating a business protects owners from the business liabilities at the cost of higher registration fees, extra paper work, and usually more complex legal compliance requirements. The higher cost associated with starting and maintaining an incorporated business works as a sorting mechanism that is likely to attract individuals more suited to succeed as entrepreneurs. As a result, the incorporated self-employed individuals not only differ from the unincorporated self-employed in a wide range of personal characteristics such as ability, risk aversion, parental characteristics, teenage experience, etc. but also earn significantly different payoffs in the labor market (Levine and Rubinstein, 2017). 
any self-employment, incorporated self-employment, and unincorporated self-employment as observed in the ASEC.

The key explanatory variable is the state-level supply of immigrant entrepreneurs, which is the number of immigrant entrepreneurs operating a business in a state in a particular year. For each state, this variable is constructed by counting the number of immigrants reporting self-employment as the longest-held job in a given year. ${ }^{11}$ For distinct analysis of any selfemployment, incorporated self-employment, and unincorporated self-employment, I construct separate measures for the overall supply of immigrant entrepreneurs, incorporated immigrant entrepreneurs, and unincorporated immigrant entrepreneurs. While constructing these state level aggregate measures, I use the same definition of self-employment in creating indicators for outcome variable. For the convenience of presenting regression coefficients, all supply of immigrant entrepreneurs measures are expressed in 100,000s in regression models.

In addition to the key predictor, the regression models control for individual and state characteristics potentially correlated with the outcome variables. The individual level controls include age, educational attainment, gender, marital status, race, number of children, and city residence status. ${ }^{12}$ These variables are shown to be theoretically and empirically important determinants of self-employment (Robinson and Sexton, 1994; Zissimopoulos and Karoly, 2007; Simoes et al., 2015; Ghimire and Maclean, 2015; Bailey, 2017). The state level controls in main regression include state population (in millions), state-fixed effects, and year fixed effects. The state and year fixed effects respectively account for unobserved state and year level factors that may be correlated with the key explanatory variable. ${ }^{13}$

\section{Methods}

\subsection{The baseline model}

Theoretical foundation for this analysis is the conceptual framework of self-employment outlined in Borjas (1986). ${ }^{14}$ For each type of self-employment - that is, any self-employment, incorporated self-employment, and unincorporated self-employment - the baseline econometric model takes the form:

$$
\text { SelfEmployed }_{i s t}=\beta_{0}+\beta_{1}^{*} \text { ImmiEnt }_{s t}+X_{i s t}^{\prime} \cdot \beta_{2}+Y_{s t}^{\prime} \cdot \beta_{3}+\eta_{s}+\lambda_{t}+\varepsilon_{i s t}
$$

where SelfEmployed $_{i s t}$ indicates whether a native individual $i$ in state $s$ in the year $t$ is selfemployed, ImmiEnt ${ }_{s t}$ is the supply of immigrant entrepreneurs in state $s$ and year $t, X_{i s t}$ is the vectors of individual characteristics, $Y_{s t}$ is a vector of state level characteristics, and $\beta s$ are parameter vectors. $\eta_{s}$, and $\lambda_{t}$, are state fixed effects and year fixed effects, respectively. $\varepsilon_{i s t}$ represents the error term. Including state fixed effects in the model implies that within state

11 One concern with the use of raw numbers is that the effect of an additional immigrant entrepreneur in a populous state such as California could be very different from that of one more immigrant entrepreneur in a sparsely populated state like Wyoming. To address this issue, I control for state population in all regressions and check robustness of the results by using logarithm of the raw numbers (see Table 6) and to using entrepreneurship rates (see Table A15 in Appendix).

12 Education is coded categorically to reflect less than high school, high school, some college, college degree, and advanced degree - "less than high school" being the omitted category in all regressions. Race is coded as non-hispanic white, nonhispanic Black, hispanic, and other - "other" as the omitted category in all regressions.

13 I do not control for state unemployment rates and/or GDP measures as they are likely "bad controls" in current setting since these variables are potential outcomes of the key independent variable (Angrist and Pischke, 2008).

14 See Section 2.2 for details. 
variation in supply of immigrant entrepreneurs is used to identify the impact of immigrant entrepreneurs. ${ }^{15}$ I estimate Eq. (4) with a linear probability model (LPM) and check robustness of results to nonlinear modeling (see Table A14 in Appendix). In regression models with micro level data and group level treatment, standard errors are likely to be downward biased if not accounted for within group correlation (Bertrand et al., 2004). However, if the clusters are too few and unbalanced, as is the case in this study, clustering could lead to over rejection (Cameron and Miller, 2015). Additionally, when models control for cluster fixed effects, clustering is recommended only in the special case of heterogeneous treatment effect (Abadie et al., 2017). Following this guidance from the literature, I use heteroskedasticity robust standard errors for hypothesis testing in the main analysis and check for sensitivity of the main conclusions to clustering in the robustness checks (see Table 6).

Under the assumptions that regressors in Eq. (4) are exogenous, parameter $\beta_{1}$ estimates the impact of the supply of specific type of immigrant entrepreneurs on the specific type of entrepreneurial propensity of natives. For instance, when SelfEmployed ${ }_{\text {ist }}$ is the indicator for whether a native individual is self-employed in an incorporated business, a positive $\beta_{1}$ implies that incorporated immigrant entrepreneurs crowd in natives into incorporated businesses. Similarly when SelfEmployed ${ }_{\text {ist }}$ represents self-employment in unincorporated business, a positive $\beta_{1}$ implies that unincorporated immigrant entrepreneurs, on average, crowd in natives into unincorporated businesses.

\subsection{The instrument}

The estimates of $\beta_{1}$ obtained from Eq. (4) are unbiased and consistent only if the supply of immigrant entrepreneurs is uncorrelated with the error term conditional on the full set of controls. However, this assumption can be invalid for several reasons. First, if native individuals avoid or select states with large supply of immigrant entrepreneurs (endogenous sorting), the estimates from Eq. (4) can be biased and inconsistent. Second, it is unlikely that all micro and macro level determinants of native self-employment are accounted for in the model, so a potential omitted variable bias cannot be ruled out. Finally, endogeneity can result from reverse causality that runs from the outcome variable to the regressor of interest. To address these empirical concerns, I estimate Two Stage Least Squares (TSLS) models utilizing an instrumental variable described below.

In TSLS models, a suitable instrumental variable enables causal identification by acting as an exogenous source of variation in the endogenous regressor. Assuming monotonicity in its effect, an instrument must satisfy two conditions to ensure consistency of the estimates of $\beta_{1}$. First, the instrument must have sufficient correlation with the supply of immigrant entrepreneurs after partialling out the effect of other covariates (the relevance requirement) and second, it should not be correlated with the error term $\varepsilon$ in Eq. (4) after conditioning on other covariates (the exclusion restriction). Intuitively, we require an exogenous source of variation in the supply of immigrant entrepreneurs which does not affect native self-employment except through the channel of supply of immigrant entrepreneurs. Fortunately, the quasi experiment provided

15 Note that a variation in the supply of immigrant entrepreneurs at the level of Metropolitan Statistical Areas (MSAs) identified in the CPS would be preferable to state level variation. However, some MSAs expand to multiple states thereby making it difficult to exploit the policy instrument described later in the manuscript. 
by the implementation of the State Children's Health Insurance Program (SCHIP) across states in the late 90 s provides such variation.

To understand how SCHIP induces a plausibly exogenous variation in the supply of immigrant entrepreneurs, one needs to go back to the 1996 welfare reform. As the welfare program known as Aid to Families with Dependent Children (AFDC) received increasing criticism in the 80 s and 90 s for "disincentivizing work" and "promoting welfare dependence" among the beneficiaries, the US passed the Personal Responsibility and Work Opportunity Reconciliation Act (PRWORA) in 1996. Two most important goals of the Act were to encourage work among welfare recipients and achieve a significant decline in welfare caseloads (Clinton, 1996). To that end, PRWORA replaced AFDC program with the Temporary Assistance for Needy Families (TANF) and imposed stricter work requirements for welfare eligibility. Additionally, the Act banned immigrants who have been in the US for less than 5 years, henceforth newly arrived immigrants, from receiving federally funded means tested benefits such as TANF and Medicaid. In 1997, the Congress passed SCHIP to cover uninsured children living in low-income families that make too much to qualify for Medicaid but too little to afford private coverage. The program was rapidly implemented across states. By 2000 , every state including the District of Columbia (DC) had some form of the SCHIP. The SCHIP promised a partnership between the federal and the state governments and gave states flexibility in designing their own eligibility requirements. Taking advantage of this autonomy, 15 states including the DC, henceforth "generous states," chose to include newly arrived immigrants in their SCHIP. ${ }^{16}$ But, newly arrived immigrants in other "less generous states" remained ineligible for all types/ means of tested public health insurance. Due to the provision of the extra safety net, referred to as "generous SCHIP" hereafter, the supply of self-employed immigrants increased by up to $28 \%$ in those 15 states (Olds, 2016). The generous SCHIP increased the supply of immigrant entrepreneurs by acting through several mechanisms such as loosening liquidly constraint and reducing the risk associated with starting a business, a point I return to later in the manuscript. Because it seems unlikely that SCHIP coverage for immigrant children would directly impact the entrepreneurial propensities of the natives, the availability of generous SCHIP for immigrants makes a potentially good instrument for the supply of immigrant entrepreneurs. Specifically, the instrument takes the form of a binary variable that indicates the availability of generous SCHIP in a given state and a given year $\left(\operatorname{GenSCHIP}_{s t}\right)$. The information required to construct the instrument, that is, the information on dates of SCHIP implementation and the information on states choosing to cover the children of newly arrived immigrants, comes from Rosenbach et al. (2001) and Olds (2016) (see Table A1 in Appendix). Because the states implemented SCHIP at different times between 1997 and 2000, the policy provides within-state variation generated in different years.

There are several reasons for why the provision of SCHIP to newly arrived immigrants can increase the supply of immigrant entrepreneurs. First, in the US, adults are often compelled to work for large employers to ensure continued access to affordable insurance for themselves and their kids (Fairlie et al., 2011). Some of these adults may switch into self-employment when

16 Information on dates of SCHIP implementation and on whether states covered newly arrived immigrants is presented in Table A1 in Appendix. The generous states also provided Medicaid coverage to a select group of newly arrived adult immigrants who met eligibility criteria based on disability, age, etc. (Fortuny and Chaudry, 2011). In 2009, an amendment to the Children's Health Insurance Program Reauthorization Act (CHIPRA) allowed all states to provide medical coverage to lawfully present pregnant women and children without a waiting period. 
there is a guaranteed access to publicly funded children's health insurance. Second, public health insurance helps families to save on premiums that would otherwise be paid for private coverage. Savings accumulated over time because of public coverage may ease liquidity constraint, a commonly cited obstacle to business creation (Evans and Jovanovic, 1989; Fairlie and Krashinsky, 2012). Third, the supply of immigrant entrepreneurs may increase when adults in families without any insurance coverage, who had previously chosen to remain out of labor force for child care, decide to enter the labor force due to reduced risk of leaving a child at day care or with a family member. Nevertheless, the suitability of generous SCHIP (GenSCHIP) as an instrument depends on whether GenSCHIP meets both the relevance and the excludability criteria (Angrist and Pischke, 2008). I conduct several tests to address potential concerns related to these criteria in the following section.

\section{Results}

\subsection{Descriptive statistics}

I begin with a close examination of the summary statistics presented in Table 1. In the pooled sample that includes both the natives and the immigrants sampled during 1994-2016 period, the overall self-employment rate, defined as the proportion of self-employed individuals in

Table 1 Summary statistics

\begin{tabular}{|c|c|c|c|}
\hline Sample & All & Natives & Immigrants \\
\hline \multicolumn{4}{|l|}{ Outcome variables } \\
\hline Self-employed & 0.0961 & 0.0950 & 0.101 \\
\hline Incorporated self-employed & 0.0342 & 0.0345 & 0.0330 \\
\hline Unincorporated self-employed & 0.0619 & 0.0606 & 0.0684 \\
\hline \multicolumn{4}{|l|}{ Control variables } \\
\hline Age & 41.28 & 41.41 & 40.66 \\
\hline Female & 0.471 & 0.481 & 0.422 \\
\hline Less than high school & 0.0815 & 0.0494 & 0.239 \\
\hline High school & 0.295 & 0.300 & 0.271 \\
\hline Some college & 0.285 & 0.306 & 0.179 \\
\hline College degree & 0.224 & 0.231 & 0.192 \\
\hline Advanced degree & 0.114 & 0.113 & 0.119 \\
\hline White & 0.677 & 0.776 & 0.197 \\
\hline Black & 0.108 & 0.113 & 0.0838 \\
\hline Other race & 0.214 & 0.111 & 0.719 \\
\hline Hispanic & 0.147 & 0.0817 & 0.468 \\
\hline Number of family members under 18 & 0.807 & 0.765 & 1.011 \\
\hline Lives in a metropolitan & 0.852 & 0.832 & 0.947 \\
\hline State population (millions) & 7.661 & 7.124 & 1.029 \\
\hline Observations & $1,361,196$ & $1,111,850$ & 249,346 \\
\hline
\end{tabular}

Note: Data span 1994-2016 from the ASEC of the CPS. All foreign-born individuals are categorized as immigrants. CPS sample weights applied.

ASEC, Annual Social and Economic Supplement; CPS, Current Population Survey. 
Table 2 Summary statistics: incorporated vs. unincorporated

\begin{tabular}{lccccc}
\hline \multirow{2}{*}{ Sample } & \multicolumn{2}{c}{ Natives } & & \multicolumn{2}{c}{ Immigrants } \\
\cline { 2 - 3 } \cline { 5 - 6 } & Incorp. & Unincorp. & & Incorp. & Unincorp. \\
\hline Age & 46.33 & 44.91 & & 45.39 & 43.73 \\
Female & 0.278 & 0.402 & & 0.285 & 0.358 \\
Less than high school & 0.0265 & 0.0633 & & 0.0787 & 0.243 \\
High school & 0.229 & 0.301 & & 0.247 & 0.303 \\
Some college & 0.274 & 0.301 & & 0.179 & 0.175 \\
College degree & 0.290 & 0.210 & & 0.285 & 0.182 \\
Advanced degree & 0.181 & 0.125 & & 0.210 & 0.0978 \\
White & 0.902 & 0.854 & & 0.374 & 0.253 \\
Black & 0.0402 & 0.0614 & 0.0560 & 0.0591 \\
Hispanic & 0.0358 & 0.0567 & & 0.238 & 0.450 \\
Number of family members under 18 & 0.851 & 0.803 & & 1.021 & 1.028 \\
Lives in a metropolitan city & 0.853 & 0.772 & & 0.962 & 0.943 \\
Observations & 39,007 & 67,829 & & 7,846 & 16,518 \\
\hline
\end{tabular}

Note: Data span 1994-2016 from the ASEC of the CPS. All foreign-born individuals are categorized as immigrants. CPS sample weights applied.

ASEC, Annual Social and Economic Supplement; CPS, Current Population Survey.

non-agricultural labor force, is approximately 9.61\%. Of the 9.61\%, 6.06\% are self-employed in unincorporated businesses and only $3.42 \%$ are self-employed in incorporated businesses. That a significantly smaller number of entrepreneurs chose to incorporate their businesses, in spite of a number of legal benefits including the advantage of limited liability, indicates that incorporated self-employed individuals may indeed be different from unincorporated self-employed in certain aspects. The third and fourth columns in Table 1 show that the ratio of incorporated to unincorporated self-employed individuals is similar across native and immigrant groups. In terms of demographic characteristics, the natives in the sample are slightly older, slightly more educated, significantly more white, and have fewer children in the family.

Table 2 presents summary characteristics of the self-employed natives and self-employed immigrants separated by self-employment types. The statistics demonstrate that incorporated entrepreneurs differ from the unincorporated in various ways. For example, the incorporated self-employed individuals are, on average, older - therefore, with potentially longer labor market experience - and more educated than the unincorporated self-employed. Similarly, incorporated self-employed are more likely to be married, have more children, and are more likely to live in metropolitan areas than their unincorporated counterparts. Women and minorities (Blacks and Hispanics) have a better representation in unincorporated than incorporated businesses. These differences are reflected within both native and immigrant groups and further support the unique treatment of the two types of self-employment.

\subsection{Baseline results}

Selected results generated in the baseline model are presented in Table 3. These estimates are obtained from estimating Eq. (4) by Ordinary Least Squares. Only coefficients on immigrant 
Table 3 Impact of immigrant entrepreneurs on entrepreneurial propensities of natives: LPM

\begin{tabular}{lccc}
\hline Outcome & $\begin{array}{c}\text { Any self- } \\
\text { employment }\end{array}$ & $\begin{array}{c}\text { Incorporated } \\
\text { self-employment }\end{array}$ & $\begin{array}{c}\text { Unincorporated } \\
\text { self-employment }\end{array}$ \\
\hline $\begin{array}{l}\text { Entrepreneurial propensity of } \\
\text { natives: }\end{array}$ & 0.0950 & 0.0345 & 0.0606 \\
Immigrant entrepreneurs & $0.0035^{\star \star}$ & $0.0064^{\star \star \star}$ & $0.0025^{\star}$ \\
Observations & $(0.0014)$ & $(0.0017)$ & $(0.0014)$ \\
\hline
\end{tabular}

Note: Data span 1994-2016 from the ASEC of the CPS. Dependent variable is binary indicator for being an entrepreneur. The supply of immigrant entrepreneurs is expressed in 100,000 s. All models control for demographic characteristics (age, marital status, education, race, number of children, and city residence status), state population (millions), state fixed effects, and year fixed effects. Robust standard errors are reported in parentheses.

ASEC, Annual Social and Economic Supplement; CPS, Current Population Survey; LPM, linear probability model.

${ }^{*} p<0.10$.

${ }^{* *} p<0.05$.

${ }^{* \star *} p<0.01$.

entrepreneurs (ImmiEnt) are shown for brevity (see Table A2 in Appendix for coefficients on full set of controls). All models control for individual characteristics, state level characteristics, state fixed effects, and year fixed effects. All coefficients in Table 3 are positive and statistically significant at conventional levels. Specifically, estimates in second column suggest that an increase of 100,000 self-employed immigrants (of any type) increases the entrepreneurial propensity of natives, on average, by 0.0035 percentage points. Given that only approximately $9.5 \%$ of natives are self-employed, it amounts to a $3.6 \%$ increase in the supply of native entrepreneurs. Similarly the third column shows that an increase of 100,000 incorporated immigrants increases the native propensity of incorporated self-employment by 0.0064 percentage points. Finally, the fourth column in Table 3 shows that an increase of 100,000 unincorporated immigrants increases the native propensity of unincorporated self-employment by 0.0025 percentage points. Overall, Table 3 indicates positive effect of immigrant entrepreneurship on native entrepreneurial propensities. However, as discussed earlier in the manuscript, the LPM estimates are likely to be biased due to endogeneity. Therefore, I report results from the preferred instrumental variable model in the following subsection.

\subsection{Results from instrumental variable model}

\subsubsection{Instrument strength}

First, I conduct tests to check if the instrument is sufficiently correlated with the endogenous regressor. To this end, I plot supply of immigrant entrepreneurs in generous and less generous states for several years before and after the policy implementation (see Figure 1). While the data for incorporated self-employment are quite noisy, the post SCHIP bump in immigrant entrepreneurs is clear in the case of all types and more so in the case of unincorporated type. In addition to comparing the overall trends in generous and less generous states, I also contrast raw trends for various demographic groups that are likely to receive a differential impact 
Figure 1 Pre and Post Policy Trends in the Supply of Immigrant Entrepreneurs.

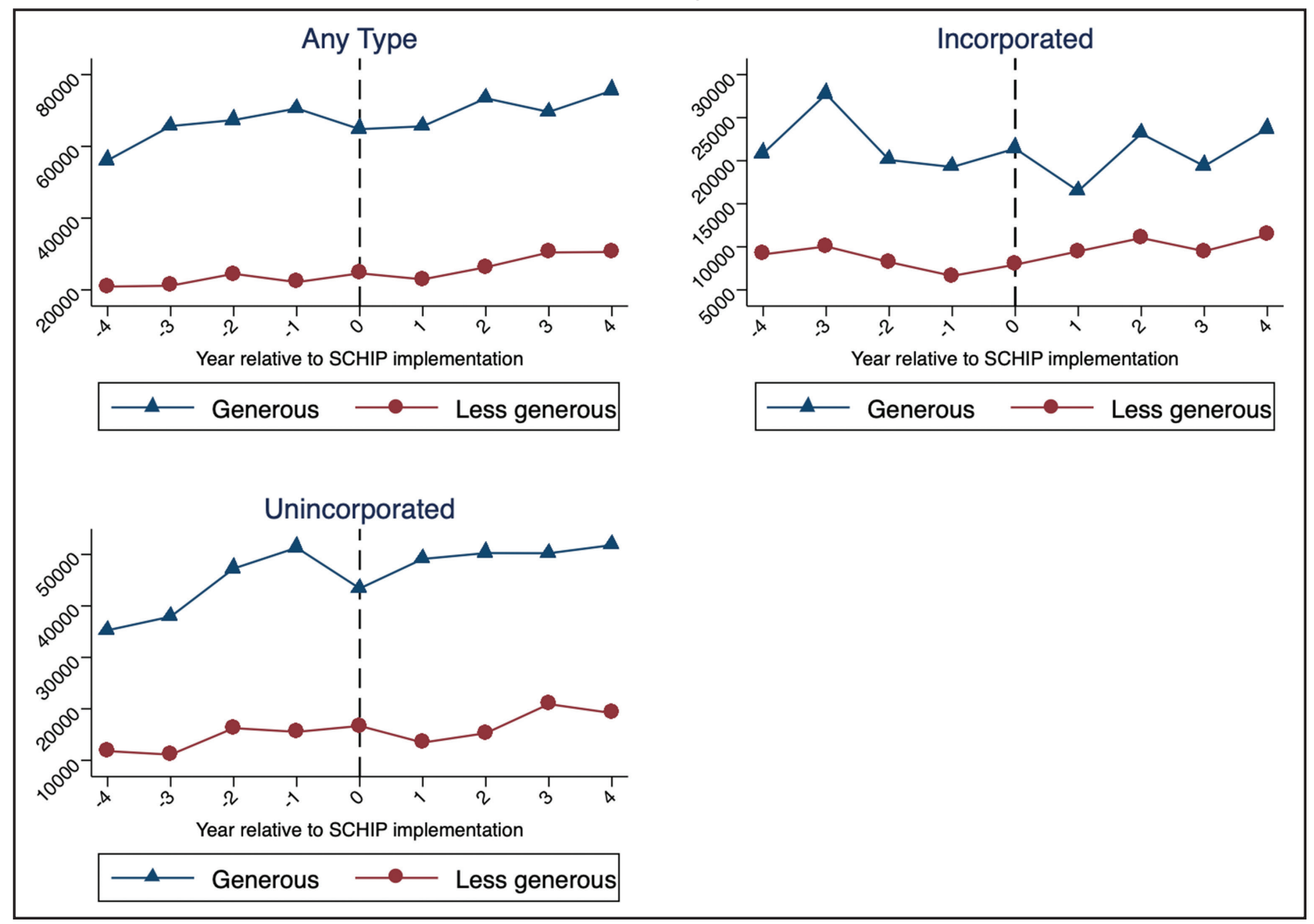

Notes: Data span 1994-2016 from the ASEC of the CPS. Trends are for the supply of immigrant entrepreneurs immediately prior to and after the implementation of SCHIP. Only 4 years prior to and after the policy implementation are shown in figure. See text for further details. ASEC, Annual Social and Economic Supplement; CPS, Current Population Survey; SCHIP, State Children's Health Insurance Program.

from SCHIP. For example, since SCHIP benefits are related to childbearing and childcare, one may expect to see a bigger impact on immigrants with no children than on those with children. Similarly, a bigger impact may be expected, ex ante, for younger immigrants (compared to older who are past the reproductive age). ${ }^{17} \mathrm{~A}$ differential impact is also likely in terms of immigrants' length of stay in the US as SCHIP benefits in generous and less generous states technically differed only for those who have been in the country for less than 5 years. These trends are presented side by side in Figure 2. It is reassuring to see the expected differential impacts, although a bit less pronounced in the young versus old category than along other two dimensions.

Next, I estimate first stage regressions for each entrepreneurship type. As the instrument varies only from 1997 through 2008, the analysis sample for IV estimates spans the period from 1997 to 2008. Estimates from the first stage regressions of the TSLS models, presented in Table 4, show that the instrument (generous SCHIP) is strongly correlated with the supply of all three measures of the supply of immigrant entrepreneurs. ${ }^{18}$ After controlling for other

17 Immigrants more than 40 years old are categorized as old.

18 See Table A3 in Appendix for coefficients on full set of controls. 
Figure 2 Pre- and Post-Policy Trends in the Supply of Immigrant Entrepreneurs with Various Attributes.

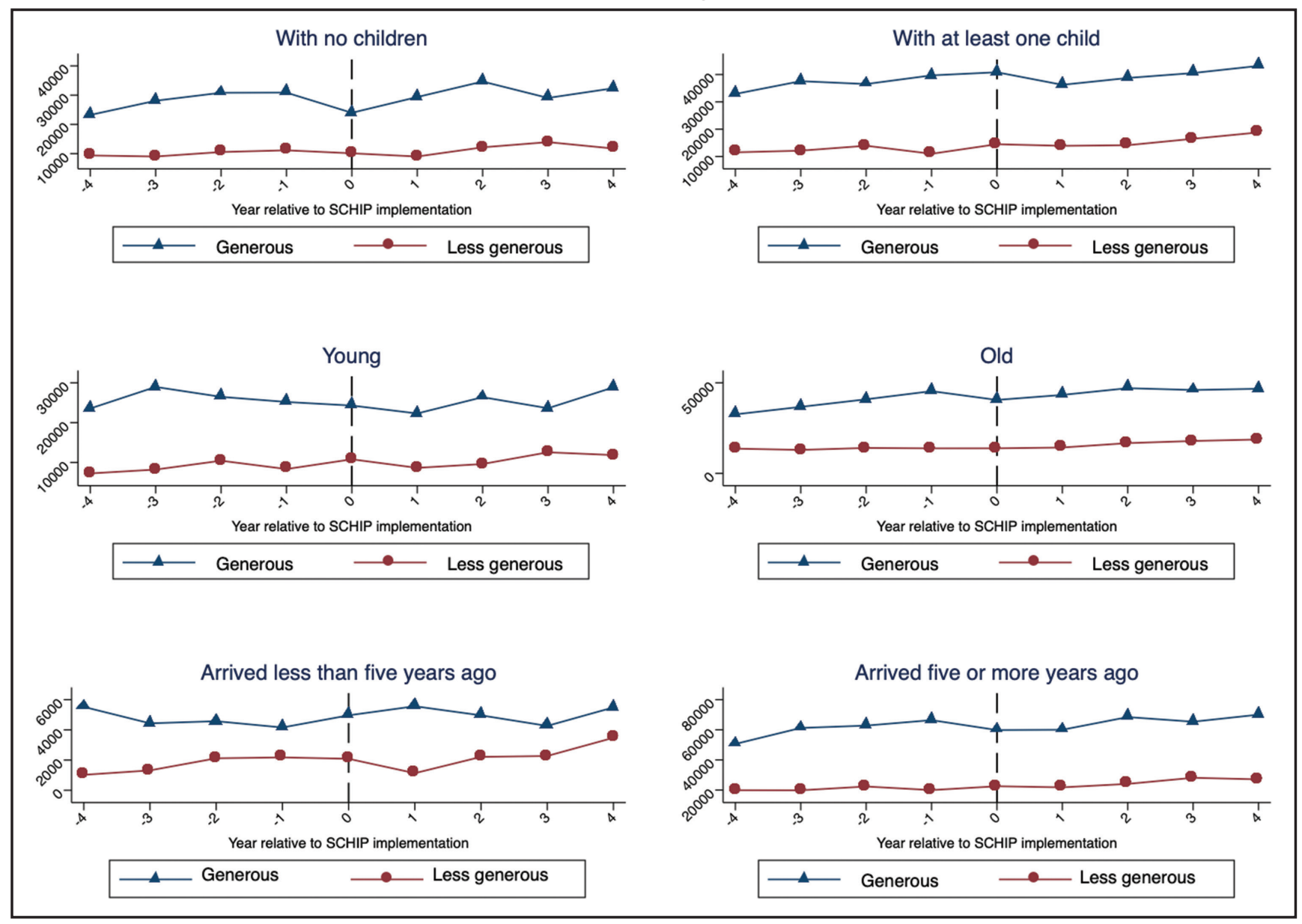

Notes: Data span 1994-2016 from the ASEC of the CPS. Trends are for the supply of immigrant entrepreneurs immediately prior to and after the implementation of SCHIP. Only 4 years prior to and after the policy implementation are shown in figure. See text for further details. ASEC, Annual Social and Economic Supplement; CPS, Current Population Survey; SCHIP, State Children's Health Insurance Program.

independent variables, the provision of SCHIP coverage for the children of newly arrived immigrants is associated with an increase of any type immigrant entrepreneurs by 11,600 (recall that the immigrant entrepreneurs are recorded in 100,000s), incorporated immigrant entrepreneurs by 4,930, and unincorporated immigrant entrepreneurs by 6,680. These effects are all significant at $1 \%$ level. The F-statistics for joint significance of excluded instruments (only one this this case) in the first stage for all first stage regressions are much larger than the generally accepted critical values of 10 . Thus I conclude that the instrument is sufficiently strong (Stock et al., 2005).

The first stage estimates imply an increase of $8.04 \%, 11.79 \%$, and $6.52 \%$ in the supply of any type, incorporated, and unincorporated immigrant entrepreneurs respectively. ${ }^{19}$ The effect sizes obtained here are somewhat smaller but broadly consistent with results presented by Olds (2016). Other estimates of the relationship between health insurance

19 The first stage estimates show a strong impact of generous SCHIP on the "stock" of immigrant entrepreneurs. As the ASEC includes information on self-employment status during the time of survey and one year prior to that, I construct two separate "flow" measures of immigrant entrepreneurship -the number and the proportion of immigrants entering entrepreneurship every year - using the method outlined in Abramowitz, Dillender, et al. (2017). Then, I check the impact of SCHIP on these measures using the exact controls used in the first stage regression. The results presented in Table A16 in Appendix show that SCHIP had a significant positive impact on immigrant's entry into entrepreneurship. 
Table 4 First-stage regressions: impact of generous SCHIP on supply of immigrant entrepreneurs

\begin{tabular}{lccc}
\hline Outcome & $\begin{array}{c}\text { Any self- } \\
\text { employment }\end{array}$ & $\begin{array}{c}\text { Incorporated } \\
\text { self-employment }\end{array}$ & $\begin{array}{c}\text { Unincorporated } \\
\text { self-employment }\end{array}$ \\
\hline $\begin{array}{l}\text { Average supply of immigrant } \\
\text { entrepreneurs: }\end{array}$ & 144,200 & 41,800 & 102,400 \\
Generous SCHIP & $0.1160^{\star \star \star}$ & $0.0493^{\star \star \star}$ & $0.0668^{\star \star \star}$ \\
& $(0.0025)$ & $(0.0009)$ & $(0.0018)$ \\
First stage F-stat & $2,101.30$ & $2,697.76$ & $1,374.92$ \\
Observations & 609,365 & 609,365 & 609,365 \\
\hline
\end{tabular}

Note: Data span 1997-2008 from the ASEC of the CPS. Dependent variable is supply of immigrant entrepreneur (in 100,000s). All models control for demographic characteristics (age, marital status, education, race, number of children, and city residence status), state population (millions), state fixed effects, and year fixed effects. Robust standard errors are reported in parentheses.

ASEC, Annual Social and Economic Supplement; CPS, Current Population Survey; SCHIP, State Children's Health Insurance Program.

${ }^{*} p<0.10$.

${ }^{* *} p<0.05$

${ }^{* \star *} p<0.01$.

coverage and self-employment include DeCicca (2010) who finds that the Individual Health Coverage Program of the state of New Jersey increased self-employment rate by 14 to $20 \%$ and Fairlie et al. (2011) who find that, for male workers, health insurance related entrepreneurship lock is just over $25 \%$. In light of the large effects found in previous studies, it is not surprising that generous SCHIP led to a nontrivial $8 \%$ increase in immigrant entrepreneurs in generous states. Note that, even though the variation in generous SCHIP was technically applicable only for newly arrived immigrants, in practice many immigrants who had been in the country for more than 5 years may have been affected by the policy. See Fix (1999) for details on how 1996 welfare reform affected unintended groups of immigrants due to so called "chilling effects." ${ }^{20}$

\subsubsection{Instrument validity}

Because the error itself is unobserved, there are no straight forward econometric tests to establish that the chosen instrument is uncorrelated with the error term. Nevertheless, we can check if the instrument affects the outcome variable via channels other than the endogenous regressor (Angrist and Pischke, 2008). One potential problem results from the fact

20 Besides entry into entrepreneurship, immigrant entrepreneurs moving across states chasing better benefits may potentially add to the overall increase in supply of immigrant entrepreneurs in generous states. I check this possibility using information on respondents' migration history contained in the ASEC. Results from an event study for the impact of generous SCHIP on annual inflows of immigrants are presented in Figure A1. While there is some sign of increased arrivals in fourth and fifth period post policy, no coefficient estimate is statistically significant. This indicates that inter-state migration of immigrants, while not entirely implausible, is not an important determinant of supply of immigrants in the current setting. These results are consistent with the results in Frey et al. (1996) who find that "state welfare benefits exert only minimal effects on the interstate migration" and De Jong et al. (2005) who conclude that "unemployment rate determines migration more than less stringent welfare policies." An additional check for potential effect of inter-state migration involves directly controlling for immigrant population in regression models. Accordingly, I estimate main regressions with separate controls for immigrant and native population (as opposed to the total population used in baseline regressions) and present results in Table A17 in Appendix. The results do not change qualitatively. 
that native individuals might engage in endogenous sorting behavior in which they move to or away from generous states. This happens if states' generosity toward immigrants translates into more or less generosity toward natives. For example, generous states covering newly arrived immigrants may have generous income eligibility requirements making these states more attractive for natives at the margin. On the contrary, some states providing coverage for newly arrived immigrants may be offsetting the funds by providing coverage to fewer natives by having more stringent income eligibility guidelines. To examine if the generous states differ significantly from less generous states in terms of generosity toward natives, I look at the SCHIP eligibility guidelines across states. States provide SCHIP coverage for children if the family income is below a certain percent of Federal Poverty Line (FPL). During the period under consideration, the guidelines ranged from $140 \%$ of FPL to $350 \%$ of FPL (Ross et al., 2007). To see the correlation between coverage for immigrants and overall generosity of SCHIP, I first categorize each state into a quintile in terms of eligibility guidelines, and generate an indicator variable to denote if a state falls in a particular quintile ranging from 1 to 5. The correlation (Pearson's $r$ ) between this generosity indicator and provision of coverage for newly arrived immigrants is weakly positive at 0.28 . This indicates that while overall state generosity is somewhat related with immigrant coverage, it does not rise to the level of a major concern.

A common approach to test for policy endogeneity involves conducting an event study to check the impact of policy a few leads before and a few lags after the implementation period (Angrist and Pischke, 2008). A statistically significant impact of the policy several periods before the implementation is usually considered a sign of policy endogeneity. I report the results from three event study models estimated to obtain the effect of SCHIP on the supply of immigrant entrepreneurs in Figure $3 .{ }^{21}$ Since there are no statistically significant leads for any self-employment type, it indicates that the policy in question is conditionally exogenous.

\subsubsection{IV regression results}

In Table 5, I report the second stage IV estimates of the impact of supply of immigrant entrepreneurs on the entrepreneurial propensities of natives. ${ }^{22}$ The TSLS estimates indicate that the impact of immigrant entrepreneurs on native entrepreneurial propensities is indistinguishable from zero. The estimated coefficients are positive for any type and unincorporated type, but negative for incorporated type. As is usually the case with TSLS, the effect sizes implied by the IV estimates are larger than OLS estimates. ${ }^{23}$ However, none of the coefficients are statistically significant at conventional levels and the implied effect sizes are still very modest. For example, the coefficient estimate for any self-employment type implies that an additional 100,000 immigrants - which is equivalent to an increase of approximately $70 \%$ from the average supply of 144,200 - would increase self-employment propensity of natives by 1.09 percentage points, or

21 Observations before 5 years of SCHIP are added to " -5 " bin and those beyond 5 years post SCHIP are included in the “ +5 ” bin. Then, “ -5 " is dropped as the omitted category. All additional controls included in the baseline regression are retained.

22 See Table A4 in Appendix for coefficients on full set of controls.

23 IV estimates tend to be larger and less precise than OLS as the former produces the so called Local Average Treatment Effect applicable to only "compliers" (Angrist and Pischke, 2008). Intuitively, the TSLS estimates are for the effect of marginal immigrants who were induced into entrepreneurship as a result of generous SCHIP. Therefore, one should be cautious in generalizing these effects. 
Figure 3 Event Study to Test Policy Endogeneity.

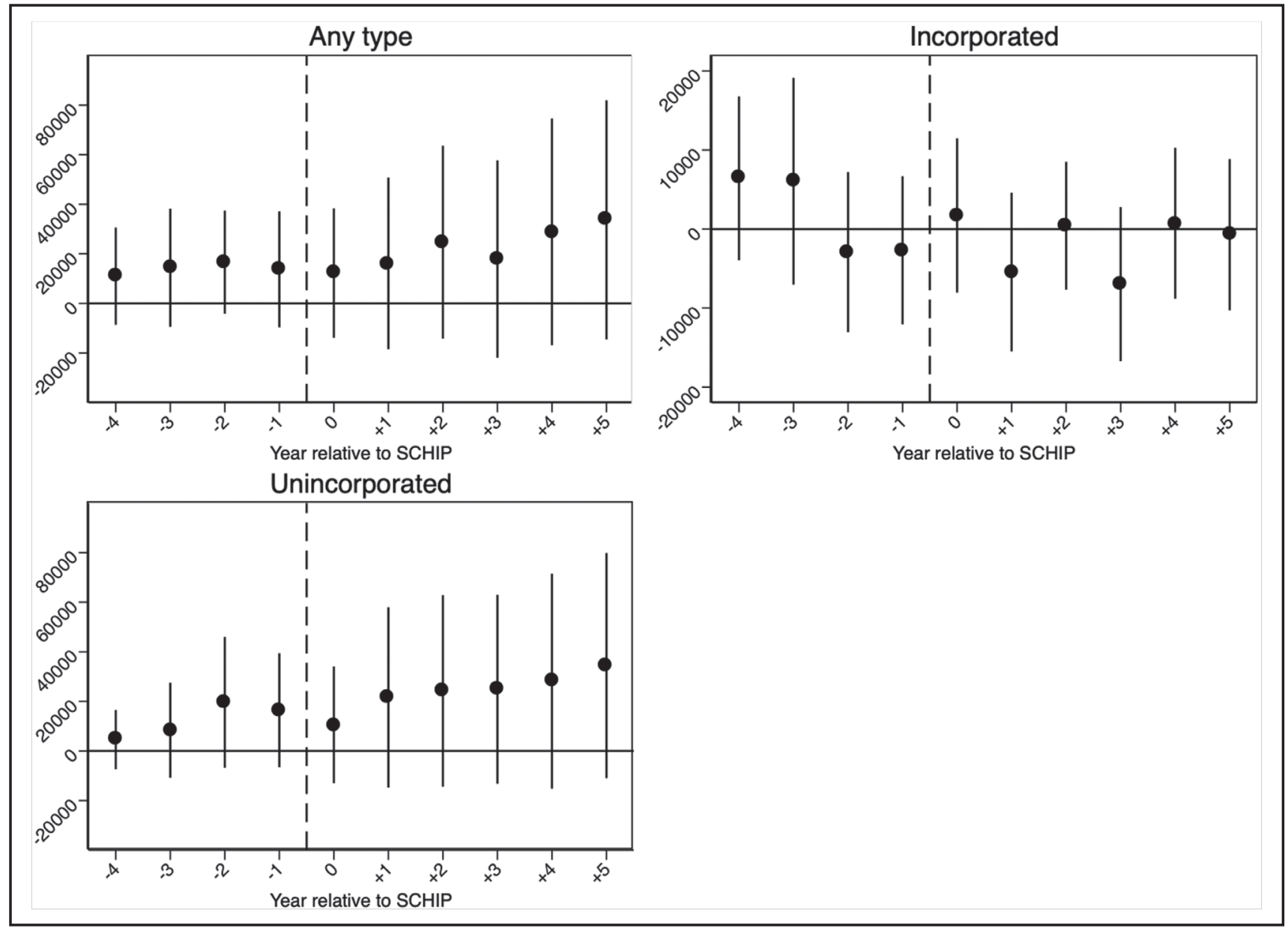

Notes: Data span 1994-2016 from the ASEC of the CPS. Observations before 5 years of SCHIP are added to “-5" bin and those beyond 5 years post SCHIP are included in the " +5 " bin. Then " -5 " is dropped as the omitted category. All additional controls included in the baseline regression are retained. Estimates with 95\% confidential interval are for the effect of generous SCHIP on the supply of immigrant entrepreneurs. See text for further detail. ASEC, Annual Social and Economic Supplement; CPS, Current Population Survey; SCHIP, State Children's Health Insurance Program.

11.47\%. Taken together, the estimates in Table 5 suggest that immigrant entrepreneurs, on the balance, neither crowd out nor crowd in natives.

\subsection{Robustness checks and extensions}

\subsubsection{Robustness to modeling, scaling, and sampling variations}

I test sensitivity of the results to five different modeling choices. First, I include in the regression model the state specific linear trends apart from the main set of controls described in Section 3. Second, I estimate Eq. (4) using Weighted TSLS by applying CPS sample weights. Third, I check whether adjusting standard errors for clustering within states would change the results of hypothesis testing. Fourth, I estimate Eq. (4) using natural log of the key explanatory variable. Fifth, I estimate Eq. (4) using an extended sample that includes data from all 51 states including DC. None of these variations, presented in Table 6, yield results qualitatively different from those reported in Table 5. 
Table 5 Impact of immigrant entrepreneurs on entrepreneurial propensities of natives: TSLS Model

\begin{tabular}{lccc}
\hline Outcome & $\begin{array}{c}\text { Any self- } \\
\text { employment }\end{array}$ & $\begin{array}{c}\text { Incorporated } \\
\text { self-employment }\end{array}$ & $\begin{array}{c}\text { Unincorporated } \\
\text { self-employment }\end{array}$ \\
\hline $\begin{array}{l}\text { Entrepreneurial propensity } \\
\text { of natives }\end{array}$ & 0.0950 & 0.0345 & 0.0606 \\
Immigrant entrepreneurs & 0.0109 & -0.0491 & 0.1268 \\
& $(0.0470)$ & $(0.0426)$ & $(0.1161)$ \\
Observations & 609,365 & 609,365 & 609,365 \\
\hline
\end{tabular}

Note: Data span 1997-2008 from the ASEC of the CPS. Dependent variable is binary indicator for being an entrepreneur. The supply of immigrant entrepreneurs is expressed in 100,000 s. All models control for demographic characteristics (age, marital status, education, race, number of children, and city residence status), state population (millions), state fixed effects, and year fixed effects. Robust standard errors are reported in parentheses.

ASEC, Annual Social and Economic Supplement; CPS, Current Population Survey; TSLS, two stage least squares.

${ }^{*} p<0.10$.

${ }^{\star \star} p<0.05$.

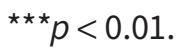

\subsubsection{Heterogeneity across groups of natives and immigrants}

Previous literature suggests heterogeneity in the impact of immigrant entrepreneurship across different groups of natives. For example, while Fairlie and Meyer (1997) suggest that immigrants have no effect on self-employment propensity of Blacks, Fairlie and Meyer (2003) suggest immigrants may crowd out non-Black natives from self-employment. To see if this is the case, I separately estimate the impact of immigrant entrepreneurs on entrepreneurial propensities of Blacks and Whites. Results are presented in Table $7 .{ }^{24}$ The second column in the upper panel of the Table 7 shows that an increase of 100,000 in any type immigrant entrepreneurs increases the entrepreneurial propensity of Blacks by 9.24 percentage points. ${ }^{25}$ Similarly, estimate in the fourth column shows that an increase of unincorporated immigrant entrepreneurs by 100,000 increases Blacks' unincorporated self-employment propensity by 12.60 percentage points. As both of these estimates are only statistically significant at $10 \%$ level, I do not wish to overemphasize the importance of these results. Further research is needed to check robustness of these findings. There is no evidence to reject the null of no effect in the case of incorporated entrepreneurship for Blacks. As no coefficients in the lower panel rise to the level of statistical significance, the null of no effect on entrepreneurship of Whites cannot be rejected.

In addition, I investigate heterogeneity of immigrant entrepreneurship across skill levels of natives. For this exercise, I define all natives with at least a college degree as high skilled individuals and those without a college degree as low skilled individuals. As presented in Tables A9-A12 in Appendix, there is no evidence to reject the null of no effect in any of the two groups of natives.

Another dimension along which a differential impact may be expected is the country of origin of the parents of natives. Since natives with at least one foreign born parent (often

24 See Tables A5-A8 in Appendix for estimates on full set of controls.

25 Recall that this is the effect of increasing the supply of immigrant entrepreneurs by almost $70 \%$. 
Table 6 Sensitivity to modeling and sampling choices: TSLS estimates

\begin{tabular}{|c|c|c|c|}
\hline Outcome & $\begin{array}{l}\text { Any self- } \\
\text { employment }\end{array}$ & $\begin{array}{l}\text { Incorporated } \\
\text { self-employment }\end{array}$ & $\begin{array}{l}\text { Unincorporated } \\
\text { self-employment }\end{array}$ \\
\hline $\begin{array}{l}\text { Entrepreneurial propensity } \\
\text { of natives: }\end{array}$ & 0.0950 & 0.0345 & 0.0606 \\
\hline \multicolumn{4}{|l|}{ State specific linear trends } \\
\hline \multirow[t]{2}{*}{ Immigrant entrepreneurs } & 0.0080 & 0.0875 & -0.0005 \\
\hline & $(0.0161)$ & $(0.0993)$ & $(0.0150)$ \\
\hline Observations & 609,352 & 609,352 & 609,352 \\
\hline \multicolumn{4}{|l|}{ Weighted least squares } \\
\hline \multirow[t]{2}{*}{ Immigrant entrepreneurs } & 0.0130 & -0.0320 & 1.2307 \\
\hline & $(0.0667)$ & $(0.0407)$ & $(1.9806)$ \\
\hline Observations & 609,365 & 609,365 & 609,365 \\
\hline \multicolumn{4}{|l|}{ Clustered standard errors } \\
\hline \multirow[t]{2}{*}{ Immigrant entrepreneurs } & 0.0109 & -0.0491 & 0.1268 \\
\hline & $(0.0611)$ & $(0.1231)$ & $(0.3590)$ \\
\hline Observations & 609,365 & 609,365 & 609,365 \\
\hline \multicolumn{4}{|l|}{ Logged explanatory variable } \\
\hline \multirow[t]{2}{*}{ Immigrant entrepreneurs } & -0.0057 & 0.0128 & -0.0588 \\
\hline & $(0.1044)$ & $(0.0098)$ & $(0.0634)$ \\
\hline Observations & 605,156 & 605,156 & 605,156 \\
\hline \multicolumn{4}{|l|}{ Extended sample } \\
\hline \multirow[t]{2}{*}{ Immigrant entrepreneurs } & -0.0014 & -0.0537 & -0.2859 \\
\hline & $(0.0984)$ & $(0.0479)$ & $(0.3718)$ \\
\hline Observations & 806,462 & 806,462 & 806,462 \\
\hline
\end{tabular}

Note: Data span 1997-2008 from the ASEC of the CPS. Dependent variable is binary indicator for being an entrepreneur. The supply of immigrant entrepreneurs is expressed in 100,000s. All models control for demographic characteristics (age, marital status, education, race, number of children, and city residence status), state population (millions), state fixed effects, and year fixed effects. Except explicitly stated, robust standard errors are reported in parentheses.

ASEC, Annual Social and Economic Supplement; CPS, Current Population Survey; TSLS, two stage least squares.

${ }^{*} p<0.10$.

${ }^{\star \star} p<0.05$.

${ }^{\star * \star} p<0.01$.

referred to as the second generation immigrants in the migration literature) are likely to have a distinct social capital, international networks, and exposure to ethnic enclaves compared to natives without any foreign born parents, there is a potential for a differential impact of immigrant entrepreneurs on these two groups. I check for heterogeneity across these groups and present results in Table A13 in Appendix. Interestingly, all coefficient estimates for natives with at least one parent of foreign origin are negative although none statistically significant. For natives with no foreign born parents, only one of the three estimates is negative while none is statistically significant. While we cannot rule out the null hypothesis of no differential impact form these estimates, the signs of coefficients are 
Table 7 Heterogeneity in the impact of immigrant entrepreneurs across races of natives: TSLS estimates

\begin{tabular}{lccc}
\hline Outcome & $\begin{array}{c}\text { Any self- } \\
\text { employment }\end{array}$ & $\begin{array}{c}\text { Incorporated } \\
\text { self-employment }\end{array}$ & $\begin{array}{c}\text { Unincorporated } \\
\text { self-employment }\end{array}$ \\
\hline $\begin{array}{l}\text { Blacks } \\
\text { Entrepreneurial propensity of } \\
\text { natives: }\end{array}$ & 0.0469 & 0.0126 & 0.0343 \\
Immigrant entrepreneurs & $0.0924^{*}$ & 0.0217 & $0.1260^{\star}$ \\
First stage F stat & $(0.0519)$ & $(0.0843)$ & $(0.0662)$ \\
Observations & 442.68 & 157.00 & 369.79 \\
\hline Whites & 64,163 & 64,163 & 64,163 \\
Entrepreneurial propensity of & 0.1121 & & 0.0706 \\
natives: & & 0.0414 & \\
Immigrant entrepreneurs & 0.0434 & -0.0432 & 0.5106 \\
& $(0.1014)$ & $(0.0729)$ & $(0.5606)$ \\
First stage F stat & 280.89 & 731.16 & 12.25 \\
Observations & 461,397 & 461,397 & 461,397 \\
\hline
\end{tabular}

Note: Data span 1997-2008 from the ASEC of the CPS. Dependent variable is binary indicator for being an entrepreneur. The supply of immigrant entrepreneurs is expressed in 100,000 s. All models control for demographic characteristics (age, marital status, education, race, number of children, and city residence status), state population (millions), state fixed effects, and year fixed effects. Robust standard errors are reported in parentheses.

ASEC, Annual Social and Economic Supplement; CPS, Current Population Survey; TSLS, two stage least squares.

${ }^{*} p<0.10$.

${ }^{\star \star} p<0.05$.

${ }^{\star \star \star} p<0.01$.

consistent with the idea that immigrant entrepreneurs may have more substitutability with respect to natives who are second generation immigrants than with natives who have a longer ancestry in the US. ${ }^{26}$

Immigrant entrepreneurs in the US vary by national origin in terms of resource utilization, firm size, firm type, and markets served (Min \& Bozorgmehr, 2000; Saxenian, 2002; Hart \& Acs, 2011). An obvious question that emerges from this observation is whether there exists heterogeneity in the impact of immigrant entrepreneurs with different national origin. Thus, I explore the distinct impact of the four largest ethnic immigrant groups in the US - Mexicans (16.8\%), Indians (4.17\%), Chinese (3.25\%), and Filipinos (2.68\%) - on native entrepreneurial propensities. ${ }^{27}$ Based on the second stage estimates from IV models, the null hypothesis that there is no effect of any of the four ethnic groups on native self-employment cannot be rejected. Unfortunately, the instrument - generous SCHIP- does not pass the strength test in some of these regressions. Hence these results are not credible enough to conclude either way and are

26 Yet another dimension along which there may be heterogeneous impact of immigrant entrepreneurs is natives' wealth. Since liquidity constraint plays an important role in business creation, it would be interesting to see if immigrant entrepreneurship would have distinct impact on natives with varying levels of net worth (Fairlie and Krashinsky, 2012). Unfortunately, despite being an excellent source of data on respondents' income, ASEC lacks data on individual's net worth.

27 Based on author's calculation using a pooled sample of 23-64 year old individuals surveyed by CPS from $1994-2016$. 
not reported here. I encounter the same issue of weak instruments when the sample is divided across industries. In unreported regressions, I estimate the effect of immigrant entrepreneurs in top four industries by immigrant entrepreneur participation: trade (18.8\%), construction (15.9\%), manufacturing (8.6\%), and transport (5.7\%). There is no evidence for crowd in or crowd out in any of the four industries but one cannot be confident regarding these findings due to weak instrument issue. ${ }^{28}$

\section{Conclusion}

Migration literature across disciplines discusses immigrant entrepreneurship as one of many benefits of immigration. However, little work has been done to establish a causal link, if any, between immigrant entrepreneurship and native entrepreneurship. Exact nature and magnitude of this effect has important implications for not only the discourse related to the impact of immigration on welfare of natives but also on the national and local policies for entrepreneurship development. This study has exploited a plausibly exogenous policy variation to examine the causal impact of a change in supply of immigrant entrepreneurs on native entrepreneurial propensity. Specifically, the analysis takes advantage of a feature of SCHIP that increased the number of immigrant entrepreneurs in select states and not in others. In contrast to what is suggested by previous research including Fairlie and Meyer (2003), analysis in this study does not yield any evidence to suggest that immigrant entrepreneurs, on the balance, displace native entrepreneurs. On the contrary, I find some indication that immigrant entrepreneurs may help increase business ownership rates among Blacks, mainly driven by "crowding-in" effects in unincorporated self-employment. The latter finding needs further investigating, but is consistent with the well-established idea that immigrants often capitalize on business opportunities within own ethnic markets and non-ethnic minority markets before starting to compete with more mainstream businesses (Yoon, 1995). Additional subsample analyses exploring the potential impact of immigrant entrepreneurs on low-skilled versus high-skilled natives and natives with at least one foreign born parent versus those without also yield null results.

Several questions emerge from the analysis in this paper. For example, what effect, if any, do immigrant entrepreneurs have on (i) earnings of self-employed natives, (ii) employment levels of natives, and (iii) wage earnings of employed natives. Another equally important question is whether self-employed immigrants are overall economically better off than employed immigrants. Implications for overall impact of immigration on welfare of natives, and by extension the specific guidance with respect to immigration policies, depend on answers to these questions. An in-depth investigation of these questions is left for future research. Overall the findings of this paper are more aligned with theories: (i) that portray immigrants as complements to natives in the self-employment market and (ii) those that view entrepreneurship as a creative process which leads to formation of innovative business opportunities.

Policywise, results of this paper, when viewed in conjunction with prior findings, point toward the benefit of attracting immigrant entrepreneurs, especially as they seem to promote entrepreneurship among minorities. Although many low skilled immigrants enter entrepreneurship as a result of weaker labor market prospects and therefore may not necessarily be

28 That the instrument is not strong enough when looking at only the top four groups by national origin or by industry indicates that an important chunk of the variation in the supply of immigrant entrepreneurs is coming from other groups. 
the most sought out examples from the entrepreneurship development perspective, many in the high tech sector create businesses that are at par with native-owned businesses (Kerr \& Kerr, 2020). If immigrant-owned businesses are indeed generating employment, increasing productivity, and enhancing international engagement without displacing natives from similar opportunities, promoting entrepreneurship among current immigrants and attracting potential entrepreneurs from abroad becomes a no-brainer. In fact, several immigrant receiving countries have already implemented immigration policies that provide preferential treatment to potential business owners. For example, Canada, Australia, and the United Kingdom provide special visas by the name of "start up visa," "entrepreneur visa," and "business talent visa," respectively, and the US provides "green card through investment" under the employment-based category EB-5. The US also has provision to allow permanent residence to potential entrepreneurs under categories like "national interest waiver" and "exceptional ability in business" under the employment-based category EB-1. However, strict quantity limits, long backlogs, and frequent administrative changes severely hamper the potential benefits of these policies (Bier, 2020). Based on the potential benefits of immigrant entrepreneurship cited in prior literature and the absence of any displacement effect on natives, policy makers should work to expand entrepreneurship visas and eliminate administrative hurdles to foster a business friendly environment.

\section{Declarations}

\section{Availability of data and material}

Data is publicly available from Center for Economic and Policy Research, Washington, DC. at http://ceprdata. org/cps-uniform-data-extracts/march-cps-supplement/march-cps-data/

\section{Competing interests}

The author states that there is no conflict of interest.

\section{Funding}

The author states that he received no funding.

\section{Acknowledgements}

I am thankful to Douglas Webber, Catherine Maclean, Michael Leeds, Amelie Constant, James Bailey, S Anukriti, Kabir Dasgupta, and participants at several seminars and conferences where I presented this work for their valuable comments.

\section{References}

Abadie, Alberto; Susan Athey; Guido W Imbens; Jeffrey Wooldridge (2017): When Should you Adjust Standard Errors for Clustering? Technical Report, National Bureau of Economic Research.

Abramowitz, Joelle; Marcus Dillender (2017): Considering the use of stock and ow outcomes in empirical analyses: An examination of marriage data. US Census Bureau, Center for Economic Studies.

Ackerman, David; Gerard Tellis (2001): Can Culture Affect Prices? A Cross-Cultural Study of Shopping and Retail Prices. Journal of Retailing 77(1), 57-82.

Aliaga-Isla, Roco; Alex Rialp (2013): Systematic Review of Immigrant Entrepreneurship Literature: Previous Findings and Ways Forward. Entrepreneurship \& Regional Development 25(9-10), 819-844.

Angrist, Joshua D.; Jörn-Steffen Pischke (2008): Mostly Harmless Econometrics: An Empiricist's Companion. Princeton University Press, Princeton, NJ.

Azoulay, Pierre; Benjamin Jones; J. Daniel Kim; Javier Miranda (2020): Immigration and Entrepreneurship in the United States. Technical Report, National Bureau of Economic Research.

Bailey, James (2017): Health Insurance and the Supply of Entrepreneurs: New Evidence from the Affordable Care Act. Small Business Economics 49(3), 627-646.

Bertrand, Marianne; Esther Duflo; Sendhil Mullainathan (2004): How Much Should We Trust Differences-In-Differences Estimates? Quarterly Journal of Economics 119(1), 249-275. 
Bier, David (2020): Backlog for Skilled Immigrants Tops 1 Million: Over 200,000 Indians Could Die of Old Age While Awaiting Green Cards. Cato Institute, Immigration Research and Policy Brief 18.

Blanchflower, David G.; Andrew J. Oswald (1998): What Makes an Entrepreneur? Journal of Labor Economics 16(1), 26-60.

Borjas, George J. (1986): The self-employment experience of immigrants. Journal of Human Resources, 21(4), 485-506.

Borjas, George J.; Jeffrey Grogger; Gordon H. Hanson (2011): Substitution between immigrants, natives, and skill groups (No. w17461). National Bureau of Economic Research.

Borjas, George J.; Richard B. Freeman; Lawrence F. Katz; John DiNardo; John M. Abowd (1997): How much do immigration and trade affect labor market outcomes? Brookings papers on economic activity, 1997(1), $1-90$.

Bruton, Garry D.; David J. Ketchen; R. Duane Ireland (2013): Entrepreneurship as A Solution to Poverty. Journal of Business Venturing 28(6), 683-689.

Brzozowski, Jan; Marco Cucculelli; Aleksander Surdej (2017): The Determinants of Transnational Entrepreneurship and Transnational Ties? Dynamics Among Immigrant Entrepreneurs in ICT Sector in Italy. International Migration 55(3), 105-125.

Cameron, A. Colin; Douglas L. Miller (2015): A Practitioner's Guide to Cluster-Robust Inference. Journal of Human Resources 50(2), 317-372.

Card, David (1990): The impact of the Mariel boatlift on the Miami labor market. Industrial \& Labor Relations Review 43(2), 245-257.

Chassamboulli, Andri; Theodore Palivos (2014): A Search-Equilibrium Approach to the Effects of Immigration on Labor Market Outcomes. International Economic Review 55(1), 111-129.

Clinton, William J. (1996): Statement on Signing the Personal Responsibility and Work Opportunity Reconciliation Act of 1996. http://www.presidency.ucsb.edu/ws/?pid=53219.

Coad, Alex; Rekha Rao (2008): Innovation and Firm Growth in High-Tech Sectors: A Quantile Regression Approach. Research Policy 37(4), 633-648

Constant, Amelie (2014): Do Migrants take the Jobs of Native Workers? IZA World of Labor.

Dabić, Marina; Bozidar Vlačić; Justin Paul; Leo-Paul Dana; Sreevas Sahasranamam; Beata Glinka (2020): Immigrant entrepreneurship: A review and research agenda. Journal of Business Research 113, 25-38.

DeCicca, Philip (2010): Health insurance availability and entrepreneurship. Upjohn Institute Working Paper, No. 10-167.

De Jong Gordon F.; Deborah Roempke Graefe; Tanja St Pierre (2005): Welfare reform and interstate migration of poor families. Demography 42(3), 469-496.

Duleep, Harriet Orcutt; David Jaeger; Mark Regets (2012): How Immigration may Affect us Native Entrepreneurship: Theoretical Building Blocks and Preliminary Results. IZA Discussion Paper No. 6677.

Dustmann, Christian; Albrecht Glitz; Tommaso Frattini (2008): The Labour Market Impact of Immigration. Oxford Review of Economic Policy 24(3), 477-494.

Dustmann, Christian; Uta Schönberg; Jan Stuhler (2017): Labor supply shocks, native wages, and the adjustment of local employment. The Quarterly Journal of Economics 132(1), 435-483.

Evans, M. D. R. (1989): Immigrant Entrepreneurship: Effects of Ethnic Market Size and Isolated Labor Pool. American Sociological Review 54, 950-962.

Evans, David S.; Boyan Jovanovic (1989): An Estimated Model of Entrepreneurial Choice Under Liquidity Constraints. The Journal of Political Economy 97, 808-827.

Fairlie, Robert (2012). Immigrant Entrepreneurs and Small Business Owners, and Their Access to Financial Capital. U.S. Small Business Administration Report, Washington DC.

Fairlie, Robert; Bruce Meyer (1997): Does immigration hurt African-American self-employment? NBER Working Paper, (w6265).

Fairlie, Robert; Bruce Meyer (2003): The Effect of Immigration on Native Self-Employment. Journal of Labor Economics 21(3), 619-650.

Fairlie, Robert; Harry A. Krashinsky (2012): Liquidity Constraints, Household Wealth, and Entrepreneurship Revisited. Review of Income and Wealth 58(2), 279-306.

Fairlie, Robert; Kanika Kapur; Susan Gates (2011): Is Employer-Based Health Insurance A Barrier to Entrepreneurship? Journal of Health Economics 30(1), 146-162.

Fatoki, Olawale; Tilton Patswawairi (2012): The Motivations and Obstacles to Immigrant Entrepreneurship in South Africa. Journal of Social Sciences 32(2), 133-142.

Fix, Michael E. (1999): Trends in noncitizens' and citizens' use of public benefits following welfare reform: 1994-97. The Urban Institute. (Available at http://webarchive.urban.org/publications/408086.html). 
Fortuny, Karina; Ajay Chaudry (2011): A Comprehensive Review of Immigrant Access to Health and Human Services. Washington, DC: Urban Institute. http://www.urban.org/research/publication/ comprehensive-review-immigrant-access-health-and-human-services/view/full_report.

Frey, William H.; Kao-Lee Liaw; Yu Xie; Marcia J. Carlson (1996): Interstate migration of the US poverty population: immigration\pushes" and welfare magnet \pulls". Population and Environment 17(6), 491-533.

Friedberg, Rachel M.; Jennifer Hunt (1995): The Impact of Immigrants on Host Country Wages, Employment and Growth. The Journal of Economic Perspectives 9(2), 23-44.

Ghimire, Keshar Mani; Johanna Catherine Maclean (2015): Economic Conditions at School-Leaving and Self-Employment. Economics Letters 137, 154-156.

Ghimire, Keshar M. (2018): Impact of children's health insurance benefit on labor supply of adults: evidence from newly arrived immigrants. Economics Bulletin 38(1), 234-247.

Goetz, Stephan J.; Mark Partridge; Steven C. Deller; David A. Fleming (2010): Evaluating us Rural Entrepreneurship Policy. Journal of Regional Analysis and Policy 40(1), 20-33.

Gould, David M. (1994): Immigrant Links to the Home Country: Empirical Implications for US Bilateral Trade Flows. The Review of Economics and Statistics 76, 302-316b.

Haltiwanger, John; Ron S. Jarmin; Javier Miranda (2013): Who Creates Jobs? Small Versus Large Versus Young. Review of Economics and Statistics 95(2), 347-361.

Hart, David M.; Zoltan J. Acs (2011): High-Tech Immigrant Entrepreneurship in the United States. Economic Development Quarterly 25(2), 116-129.

Hipple, Steven F. (2010): Self-Employment in the United States. Monthly Labor Review 133(9), 17-32.

Hu, Wei-Yin (2000): Immigrant earnings assimilation: estimates from longitudinal data. American Economic Review 90(2), 368-372.

Hunt, Jennifer; Marjolaine Gauthier-Loiselle (2010): How much does immigration boost innovation? American Economic Journal: Macroeconomics 2(2), 31-56.

Joona, Pernilla Andersson (2011): The Native-Immigrant Income Gap Among the Self-Employed in Sweden. International Migration 49(4), 118-143.

Kahn, Shulamit; Giulia La Mattina; Megan J. MacGarvie (2017): Misfits, Stars, and Immigrant Entrepreneurship. Small Business Economics 49(3), 533-557.

Kambourov, Gueorgui; lourii Manovskii (2013): A Cautionary Note on Using (March) Current Population Survey and Panel Study of Income Dynamics Data to Study Worker Mobility. Macroeconomic Dynamics 17(1), 172-194.

Kloosterman, Robert (2000): Immigrant Entrepreneurship and the Institutional Context: A Theoretical Exploration, editor, J. Rath, in: Immigrant Businesses, 90-106, Springer, Houndmills, UK.

Kerr, Sari Pekkala; William R. Kerr (2011): Economic impacts of immigration: A survey (Tech. Rep.). National Bureau of Economic Research.

Kerr, Sari Pekkala; William R. Kerr (2016): Immigrant Entrepreneurship. Technical Report, National Bureau of Economic Research.

Kerr, Sari Pekkala; William Kerr (2020): Immigrant Entrepreneurship in America: Evidence from the Survey of Business Owners 2007 \& 2012. Research Policy 49(3), 103918.

Kerr, William R. (2008): Ethnic Scientific Communities and International Technology Diffusion. The Review of Economics and Statistics 90(3), 518-537.

Kerr, William R.; William F. Lincoln (2010): The supply side of innovation: H-1b visa reforms and US ethnic invention. Journal of Labor Economics, 28(3), 473-508.

Kwak, Min-Jung; Daniel Hiebert (2010): Globalizing Canadian Education from Below: A Case Study of Transnational Immigrant Entrepreneurship Between Seoul, Korea and Vancouver Canada. Journal of International Migration and Integration/Revue de l'integration et de la migration internationale 11(2), 131-153.

Lee, Ho Jin; Akinori Tomohara (2008): Public Health Insurance Expansions and Labour Supply of Married Women: The State Children's Health Insurance Programme. Applied Economics 40(7), 863-874.

Levine, Ross; Yona Rubinstein (2017): Smart and Illicit: Who Becomes an Entrepreneur and do they Earn More? The Quarterly Journal of Economics 132(2), 963-1018.

Light, Ivan; Angel A. Sanchez (1987): Immigrant entrepreneurs in 272 SMSAs. Sociological Perspectives 30(4), 373-399.

Lofstrom, Magnus (2002). Labor market assimilation and the self-employment decision of immigrant entrepreneurs. Journal of Population Economics, 15(1), 83-114.

Lofstrom, Magnus (2011): Low-Skilled Immigrant Entrepreneurship. Review of Economics of the Household 9(1), 25-44.

Manacorda, Marco; Alan Manning; Jonathan Wadsworth (2012): The Impact of Immigration on the Structure of Wages: Theory and Evidence from Britain. Journal of the European Economic Association 10(1), 120-151. 
Mesch, Gustavo S.; Daniel Czamanski (1997): Occupational Closure and Immigrant Entrepreneurship: Russian Jews in Israel. The Journal of Socio-Economics 26(6), 597-610.

Min, Pyong Gap; Mehdi Bozorgmehr (2000): Immigrant Entrepreneurship and Business Patterns: A Comparison of Koreans and Iranians in Los Angeles. International Migration Review 34(3), 707-738.

Olds, Gareth (2016): Immigrant Entrepreneurs and the Social Safety Net. Harvard Business School Working Paper 16-142.

Olney, William W. (2013): Immigration and firm expansion. Journal of Regional Science 53(1), 142-157.

Orrenius, Pia M.; Madeline Zavodny (2007): Does Immigration Affect Wages? A Look at Occupation-Level Evidence. Labour Economics 14(5), 757-773.

Ottaviano, Gianmarco IP; Giovanni Peri (2012): Rethinking the effect of immigration on wages. Journal of the European Economic Association 10(1), 152-197.

Peri, Giovanni (2014): Do Immigrant Workers Depress the Wages of Native Workers? IZA World of Labor.

Peroni, Chiara; Cesare AF Riillo; Francesco Sarracino (2016): Entrepreneurship and immigration: evidence from GEM Luxembourg. Small Business Economics 46(4), 639-656.

Prantl, Susanne; Alexandra Spitz-Oener (2020): The impact of immigration on competing natives' wages: Evidence from German reunification. Review of Economics and Statistics 102(1), 79-97.

Rath, Jan; Robert Kloosterman (2000): Outsiders' Business: A Critical Review of Research on Immigrant Entrepreneurship. International Migration Review 34(3), 657-681.

Robinson, Peter B.; Edwin A. Sexton (1994): The Effect of Education and Experience on Self-Employment Success. Journal of Business Venturing 9(2), 141-156.

Rosenbach, Margo; Marilyn Ellwood; John Czajka; Carol Irvin; Wendy Coupe; Brian Quinn (2001): Implementation of the State Children's Health Insurance Program: Momentum is increasing after a modest start. First annual report submitted to the Centers for Medicare \& Medicaid Services. Cambridge, MA: Mathematica Policy Research, Inc. (Available at http://www.mathematica-mpr.com/ /media/publications/PDFs/impchildhlth.pdf).

Ross, Donna Cohen; L. Cox; C. Marks (2007): Resuming the Path to Health Coverage for Children and Parents. Kaiser Commission on Medicaid and the Uninsured (January 2007), http://www.kff.org/medicaid/7608a. cfm. Accessed 27 August 2007.

Rupasingha, Anil; Stephan J. Goetz (2013): Self-Employment and Local Economic Performance: Evidence from US Counties. Papers in Regional Science 92(1), 141-161.

Saxenian, Anna Lee (2002): Silicon Valley's New Immigrant High-Growth Entrepreneurs. Economic Development Quarterly 16(1), 20-31.

Simoes, Nadia; Nuno Crespo; Sandrina B. Moreira (2015): Individual Determinants of Self-Employment Entry: What Do We Really Know? Journal of Economic Surveys 30(4), 783-806.

Stock, James H.; Motohiro Yogo (2005): Testing for Weak Instruments in Linear IV Regression. Identifica tion and Inference for Econometric Models: Essays in Honor of Thomas Rothenberg 80(4.2), 1.

Unel, Bulent (2018): Effects of Immigration on Native Entrepreneurship in the US. Technical Report.

Unel, Bulent (2019): A model of occupational choice, o_shoring and immigration. Review of International Economics 27(1), 267-289.

Van Stel, André; Martin Carree; Roy Thurik (2005): The Effect of Entrepreneurial Activity on National Economic Growth. Small Business Economics 24(3), 311-321.

Winter-Ebmer, Rudolf; Josef Zweimüller (1999): Do immigrants displace young native workers: the Austrian experience. Journal of Population Economics 12(2), 327-340.

Yoon, In-Jin (1995): The Growth of Korean Immigrant Entrepreneurship in Chicago. Ethnic and Racial Studies 18(2), 315-335.

You, Tianlong; Min Zhou (2019): Simultaneous embeddedness in immigrant entrepreneurship: global forces behind Chinese-owned nail salons in New York City. American Behavioral Scientist 63(2), 166-185.

Zissimopoulos, Julie M.; Lynn A. Karoly (2007): Transitions to Self-Employment at Older Ages: The Role of Wealth, Health, Health Insurance and Other Factors. Labour Economics 14(2), 269-295. 


\section{Appendix}

Table A1 SCHIP Implementation and Immigrant Coverage by State

\begin{tabular}{|c|c|c|}
\hline State & $\begin{array}{l}\text { Date of SCHIP } \\
\text { implementation }\end{array}$ & $\begin{array}{l}\text { Coverage for new } \\
\text { immigrants }\end{array}$ \\
\hline Alaska (AK) & March 1999 & Yes \\
\hline Alabama (AL) & February 1998 & No \\
\hline Arkansas (AR) & October 1998 & No \\
\hline Arizona (AZ) & October 1997 & No \\
\hline California (CA) & July 1998 & Yes \\
\hline Colorado (CO) & April 1998 & No \\
\hline Connecticut (CT) & October 1997 & No \\
\hline District of Columbia (DC) & September 1997 & Yes \\
\hline Delaware (DE) & October 1998 & Yes \\
\hline Florida (FL) & April 1998 & No \\
\hline Georgia (GA) & September 1998 & No \\
\hline Hawaii (HI) & January 2000 & Yes \\
\hline lowa (IA) & July 1998 & No \\
\hline Idaho (ID) & October 1997 & No \\
\hline Illinois (IL) & January 1998 & Yes \\
\hline Indiana (IN) & October 1997 & No \\
\hline Kansas (KS) & July 1998 & No \\
\hline Kentucky (KY) & July 1998 & No \\
\hline Louisiana (LA) & November 1998 & No \\
\hline Massachusetts (MA) & October 1997 & Yes \\
\hline Maryland (MD) & July 1998 & No \\
\hline Maine (ME) & July 1998 & No \\
\hline Michigan (MI) & May 1998 & No \\
\hline Minnesota (MN) & September 1998 & Yes \\
\hline Missouri (MO) & October 1997 & No \\
\hline Mississippi (MS) & July 1998 & No \\
\hline Montana (MT) & January 1998 & No \\
\hline North Carolina (NC) & October 1998 & No \\
\hline North Dakota (ND) & October 1998 & No \\
\hline Nebraska (NE) & May 1998 & Yes \\
\hline New Hampshire (NH) & May 1998 & No \\
\hline New Jersey (NJ) & February 1998 & Yes \\
\hline New Mexico (NM) & May 1998 & Yes \\
\hline Nevada (NV) & October 1998 & No \\
\hline New York (NY) & April 1998 & Yes \\
\hline Ohio $(\mathrm{OH})$ & January 1998 & No \\
\hline Oklahoma (OK) & December 1997 & No \\
\hline
\end{tabular}


Table A1 Continued

\begin{tabular}{|c|c|c|}
\hline State & $\begin{array}{l}\text { Date of SCHIP } \\
\text { implementation }\end{array}$ & $\begin{array}{c}\text { Coverage for new } \\
\text { immigrants }\end{array}$ \\
\hline Oregon (OR) & July 1998 & No \\
\hline Pennsylvania (PA) & June 1998 & Yes \\
\hline Rhode Island (RI) & October 1997 & No \\
\hline South Carolina (SC) & October 1997 & No \\
\hline South Dakota (SD) & July 1998 & No \\
\hline Tennessee (TN) & October 1997 & No \\
\hline Texas (TX) & July 1998 & No \\
\hline Utah (UT) & August 1998 & No \\
\hline Virginia (VA) & October 1998 & Yes \\
\hline Vermont (VT) & October 1998 & No \\
\hline Washington (WA) & January 2000 & Yes \\
\hline Wisconsin (WI) & April 1999 & No \\
\hline West Virginia (WV) & July 1998 & No \\
\hline Wyoming (WY) & April 1999 & No \\
\hline
\end{tabular}

Source: Rosenbach et al. (2001) and Ghimire (2018). All states covered new immigrants starting 2009.

SCHIP, State Children's Health Insurance Program. 
Table A2 Impact of Supply of Immigrant Entrepreneurs on Entrepreneurial Propensities of Natives: LPM

\begin{tabular}{|c|c|c|c|}
\hline Outcome & $\begin{array}{c}\text { Any self- } \\
\text { employment }\end{array}$ & $\begin{array}{l}\text { Incorporated } \\
\text { self-employment }\end{array}$ & $\begin{array}{l}\text { Unincorporated } \\
\text { self-employment }\end{array}$ \\
\hline $\begin{array}{l}\text { Entrepreneurial propensity } \\
\text { of natives: }\end{array}$ & 0.0950 & 0.0345 & 0.0606 \\
\hline \multirow[t]{2}{*}{ Immigrant entrepreneurs } & $0.0035^{\star \star}$ & $0.0064^{\star \star \star}$ & $0.0025^{\star}$ \\
\hline & $(0.0014)$ & $(0.0017)$ & $(0.0014)$ \\
\hline \multirow[t]{2}{*}{ Age } & $0.00310^{\star \star \star}$ & $0.00139^{\star \star \star}$ & $0.00171^{\star \star \star}$ \\
\hline & $(0.00003)$ & $(0.00002)$ & $(0.00002)$ \\
\hline \multirow[t]{2}{*}{ Female } & $-0.04504^{\star \star \star}$ & $-0.02901^{\star \star \star}$ & $-0.01603^{\star \star \star}$ \\
\hline & $(0.00055)$ & $(0.00034)$ & $(0.00045)$ \\
\hline \multirow[t]{2}{*}{ High school } & $-0.00688^{* \star *}$ & $0.00903^{\star * *}$ & $-0.01591^{\star \star \star}$ \\
\hline & $(0.00135)$ & $(0.00064)$ & $(0.00122)$ \\
\hline \multirow[t]{2}{*}{ Some college } & -0.00141 & $0.01478^{\star * \star}$ & $-0.01619^{\star \star \star}$ \\
\hline & $(0.00135)$ & $(0.00065)$ & $(0.00122)$ \\
\hline \multirow[t]{2}{*}{ College degree } & $0.00642^{\star \star \star}$ & $0.02653^{\star \star \star}$ & $-0.02011^{\star \star \star}$ \\
\hline & $(0.00141)$ & $(0.00072)$ & $(0.00125)$ \\
\hline \multirow[t]{2}{*}{ Advanced degree } & $0.01341^{\star \star \star}$ & $0.03144^{\star \star \star}$ & $-0.01804^{\star \star \star}$ \\
\hline & $(0.00156)$ & $(0.00087)$ & $(0.00135)$ \\
\hline \multirow[t]{2}{*}{ White } & $0.02559^{\star \star \star}$ & $0.01142^{\star \star \star}$ & $0.01416^{\star \star \star}$ \\
\hline & $(0.00148)$ & $(0.00085)$ & $(0.00126)$ \\
\hline \multirow[t]{2}{*}{ Black } & $-0.02389^{\star \star \star}$ & $-0.01070^{\star \star \star}$ & $-0.01320^{\star \star *}$ \\
\hline & $(0.00159)$ & $(0.00091)$ & $(0.00135)$ \\
\hline \multirow[t]{2}{*}{ Hispanic } & $-0.01709^{\star \star \star}$ & $-0.00484^{\star \star \star}$ & $-0.01226^{\star \star \star}$ \\
\hline & $(0.00161)$ & $(0.00091)$ & $(0.00137)$ \\
\hline \multirow[t]{2}{*}{ Number of children } & $0.01181^{\star \star \star}$ & $0.00626^{\star \star \star}$ & $0.00555^{\star \star \star}$ \\
\hline & $(0.00026)$ & $(0.00016)$ & $(0.00021)$ \\
\hline \multirow[t]{2}{*}{ Lives in a city } & $0.01484^{\star \star \star}$ & $-0.00430^{\star \star \star}$ & $0.01914^{\star \star \star}$ \\
\hline & $(0.00085)$ & $(0.00048)$ & $(0.00072)$ \\
\hline \multirow[t]{2}{*}{ State population } & 0.00027 & $0.00080^{\star \star}$ & -0.00043 \\
\hline & $(0.00087)$ & $(0.00037)$ & $(0.00071)$ \\
\hline Observations & $1,111,863$ & $1,111,863$ & $1,111,863$ \\
\hline
\end{tabular}

Note: Dependent variable is binary indicator for being an entrepreneur. The supply of immigrant entrepreneurs is expressed in 100,000s. All models control for demographic characteristics (age, marital status, education, race, ethnicity, number of children, and city residence status), state population (millions), state fixed effects, and year fixed effects. Robust standard errors are reported in parentheses.

LPM, linear probability model.

${ }^{*} p<0.10$.

${ }^{* *} p<0.05$.

${ }^{* \star *} p<0.01$. 
Table A3 First-stage Regressions: Association between Generous SCHIP and Supply of Immigrant Entrepreneurs

\begin{tabular}{|c|c|c|c|}
\hline Outcome & $\begin{array}{c}\text { Any self- } \\
\text { employment }\end{array}$ & $\begin{array}{l}\text { Incorporated } \\
\text { self-employment }\end{array}$ & $\begin{array}{l}\text { Unincorporated } \\
\text { self-employment }\end{array}$ \\
\hline $\begin{array}{l}\text { Average supply of immigrant } \\
\text { entrepreneurs: }\end{array}$ & 144,200 & 41,800 & 102,400 \\
\hline \multirow[t]{2}{*}{ Generous SCHIP } & $0.1160^{\star \star \star}$ & $0.0493^{\star \star \star}$ & $0.0668^{\star \star \star}$ \\
\hline & $(0.0025)$ & $(0.0009)$ & $(0.0018)$ \\
\hline \multirow[t]{2}{*}{ Age } & -0.00002 & 0.00000 & -0.00002 \\
\hline & $(0.00002)$ & $(0.00001)$ & $(0.00002)$ \\
\hline \multirow[t]{2}{*}{ Female } & 0.00024 & 0.00011 & 0.00013 \\
\hline & $(0.00046)$ & $(0.00022)$ & $(0.00038)$ \\
\hline \multirow[t]{2}{*}{ High school } & -0.00079 & 0.00056 & -0.00136 \\
\hline & $(0.00110)$ & $(0.00053)$ & $(0.00091)$ \\
\hline \multirow[t]{2}{*}{ Some college } & -0.00158 & 0.00069 & $-0.00227^{\star \star}$ \\
\hline & $(0.00111)$ & $(0.00054)$ & $(0.00092)$ \\
\hline \multirow[t]{2}{*}{ College degree } & 0.00114 & $0.00131^{\star \star}$ & -0.00017 \\
\hline & $(0.00115)$ & $(0.00056)$ & $(0.00095)$ \\
\hline \multirow[t]{2}{*}{ Advanced degree } & 0.00139 & $0.00140^{\star \star}$ & -0.00001 \\
\hline & $(0.00125)$ & $(0.00061)$ & $(0.00104)$ \\
\hline \multirow[t]{2}{*}{ White } & $-0.00704^{\star \star \star}$ & $-0.00147^{\star \star}$ & $-0.00557^{\star \star \star}$ \\
\hline & $(0.00149)$ & $(0.00064)$ & $(0.00122)$ \\
\hline \multirow[t]{2}{*}{ Black } & $-0.00916^{\star \star \star}$ & $-0.00249^{\star \star \star}$ & $-0.00667^{\star \star \star}$ \\
\hline & $(0.00166)$ & $(0.00074)$ & $(0.00136)$ \\
\hline \multirow[t]{2}{*}{ Hispanic } & $-0.00353^{\star}$ & 0.00009 & $-0.00362^{\star \star}$ \\
\hline & $(0.00182)$ & $(0.00079)$ & $(0.00150)$ \\
\hline \multirow[t]{2}{*}{ Number of children } & -0.00030 & -0.00007 & -0.00023 \\
\hline & $(0.00021)$ & $(0.00010)$ & $(0.00017)$ \\
\hline \multirow[t]{2}{*}{ Lives in a city } & $0.00456^{\star \star \star}$ & $0.00206^{\star \star \star}$ & $0.00250^{\star \star \star}$ \\
\hline & $(0.00046)$ & $(0.00024)$ & $(0.00038)$ \\
\hline \multirow[t]{2}{*}{ State population } & $0.66179^{\star \star \star}$ & $0.17862^{\star \star \star}$ & $0.48317^{\star \star \star}$ \\
\hline & $(0.00115)$ & $(0.00049)$ & $(0.00097)$ \\
\hline Observations & 609,365 & 609,365 & 609,365 \\
\hline
\end{tabular}

Note: Dependent variable is supply of immigrant entrepreneur (in 100,000s). All models control for demographic characteristics (age, marital status, education, race, ethnicity, number of children, and city residence status), state population (millions), state fixed effects, and year fixed effects. Robust standard errors are reported in parentheses.

SCHIP, State Children's Health Insurance Program.

${ }^{\star} p<0.10$.

${ }^{\star *} p<0.05$.

${ }^{\star \star \star} p<0.01$ 
Table A4 Impact of Supply of Immigrant Entrepreneurs on Entrepreneurial Propensities of Natives: Second Stage Estimates

\begin{tabular}{|c|c|c|c|}
\hline Outcome & $\begin{array}{c}\text { Any self- } \\
\text { employment }\end{array}$ & $\begin{array}{c}\text { Incorporated } \\
\text { self-employment }\end{array}$ & $\begin{array}{l}\text { Unincorporated } \\
\text { self-employment }\end{array}$ \\
\hline $\begin{array}{l}\text { Entrepreneurial propensity } \\
\text { of natives: }\end{array}$ & 0.0950 & 0.0345 & 0.0606 \\
\hline \multirow[t]{2}{*}{ Immigrant entrepreneurs } & 0.0109 & -0.0491 & 0.1268 \\
\hline & $(0.0470)$ & $(0.0426)$ & $(0.1161)$ \\
\hline \multirow[t]{2}{*}{ Age } & $0.00311^{\star \star \star}$ & $0.00134^{\star \star \star}$ & $0.00178^{\star \star \star}$ \\
\hline & $(0.00004)$ & $(0.00002)$ & $(0.00003)$ \\
\hline \multirow[t]{2}{*}{ Female } & $-0.04720^{\star \star \star}$ & $-0.03003^{\star \star \star}$ & $-0.01718^{\star \star \star}$ \\
\hline & $(0.00075)$ & $(0.00046)$ & $(0.00062)$ \\
\hline \multirow[t]{2}{*}{ High school } & $-0.00528^{\star \star \star *}$ & $0.00888^{\star \star \star}$ & $-0.01397^{\star \star \star}$ \\
\hline & $(0.00177)$ & $(0.00083)$ & $(0.00163)$ \\
\hline \multirow[t]{2}{*}{ Some college } & -0.00005 & $0.01482^{\star \star \star}$ & $-0.01457^{\star \star \star}$ \\
\hline & $(0.00178)$ & $(0.00085)$ & $(0.00164)$ \\
\hline \multirow[t]{2}{*}{ College degree } & $0.00885^{\star \star \star}$ & $0.02726^{\star \star *}$ & $-0.01832^{\star \star \star}$ \\
\hline & $(0.00186)$ & $(0.00096)$ & $(0.00166)$ \\
\hline \multirow[t]{2}{*}{ Advanced degree } & $0.01802^{\star \star \star}$ & $0.03320^{\star * *}$ & $-0.01510^{\star \star \star}$ \\
\hline & $(0.00211)$ & $(0.00118)$ & $(0.00183)$ \\
\hline \multirow[t]{2}{*}{ White } & $0.02627^{\star \star \star}$ & $0.01184^{\star \star \star}$ & $0.01499^{\star \star \star}$ \\
\hline & $(0.00213)$ & $(0.00118)$ & $(0.00193)$ \\
\hline \multirow[t]{2}{*}{ Black } & $-0.02582^{\star \star \star}$ & $-0.01105^{\star \star \star}$ & $-0.01415^{\star \star \star}$ \\
\hline & $(0.00230)$ & $(0.00126)$ & $(0.00210)$ \\
\hline \multirow[t]{2}{*}{ Hispanic } & $-0.01754^{\star \star \star}$ & $-0.00482^{\star \star \star}$ & $-0.01230^{\star \star \star}$ \\
\hline & $(0.00229)$ & $(0.00126)$ & $(0.00203)$ \\
\hline \multirow[t]{2}{*}{ Number of children } & $0.01279^{\star \star \star}$ & $0.00661^{\star \star \star}$ & $0.00620^{\star \star \star}$ \\
\hline & $(0.00035)$ & $(0.00022)$ & $(0.00029)$ \\
\hline \multirow[t]{2}{*}{ Lives in a city } & $0.01795^{\star \star \star}$ & $-0.00446^{\star \star \star}$ & $0.02224^{\star \star \star}$ \\
\hline & $(0.00117)$ & $(0.00065)$ & $(0.00103)$ \\
\hline \multirow[t]{2}{*}{ State population } & -0.00482 & 0.01032 & -0.06039 \\
\hline & $(0.03122)$ & $(0.00772)$ & $(0.05612)$ \\
\hline Observations & 609,365 & 609,365 & 609,365 \\
\hline
\end{tabular}

Note: Dependent variable is binary indicator for being an entrepreneur. The supply of immigrant entrepreneurs is expressed in 100,000s. All models control for demographic characteristics (age, marital status, education, race, ethnicity, number of children, and city residence status), state population (millions), state fixed effects, and year fixed effects. Robust standard errors are reported in parentheses.

${ }^{*} p<0.10$.

${ }^{* *} p<0.05$.

${ }^{* \star *} p<0.01$ 
Table A5 Heterogeneity in the Impact of Immigrant Entrepreneurs across Races of Natives: First Stage Estimates for Blacks

\begin{tabular}{|c|c|c|c|}
\hline Outcome & $\begin{array}{c}\text { Any self- } \\
\text { employment }\end{array}$ & $\begin{array}{c}\text { Incorporated } \\
\text { self-employment }\end{array}$ & $\begin{array}{l}\text { Unincorporated } \\
\text { self-employment }\end{array}$ \\
\hline \multirow[t]{2}{*}{ Generous SCHIP } & $0.09265^{\star \star \star}$ & $0.02986^{\star \star \star}$ & $0.06280^{\star \star \star}$ \\
\hline & $(0.00440)$ & $(0.00238)$ & $(0.00327)$ \\
\hline \multirow[t]{2}{*}{ Age } & 0.00001 & 0.00004 & -0.00004 \\
\hline & $(0.00007)$ & $(0.00003)$ & $(0.00006)$ \\
\hline \multirow[t]{2}{*}{ Female } & 0.00017 & 0.00013 & 0.00005 \\
\hline & $(0.00142)$ & $(0.00071)$ & $(0.00116)$ \\
\hline \multirow[t]{2}{*}{ High school } & -0.00049 & $0.00229^{\star}$ & -0.00278 \\
\hline & $(0.00242)$ & $(0.00133)$ & $(0.00201)$ \\
\hline \multirow[t]{2}{*}{ Some college } & $-0.00507^{\star \star}$ & $0.00230^{\star}$ & $-0.00737^{\star \star \star}$ \\
\hline & $(0.00252)$ & $(0.00137)$ & $(0.00210)$ \\
\hline \multirow[t]{2}{*}{ College degree } & 0.00107 & $0.00467^{\star \star \star}$ & -0.00360 \\
\hline & $(0.00287)$ & $(0.00152)$ & $(0.00238)$ \\
\hline \multirow[t]{2}{*}{ Advanced degree } & 0.00084 & 0.00235 & -0.00151 \\
\hline & $(0.00344)$ & $(0.00180)$ & $(0.00283)$ \\
\hline \multirow[t]{2}{*}{ Number of children } & $0.00112^{*}$ & 0.00009 & $0.00103^{\star \star}$ \\
\hline & $(0.00062)$ & $(0.00031)$ & $(0.00051)$ \\
\hline \multirow[t]{2}{*}{ Lives in a city } & 0.00309 & 0.00175 & 0.00134 \\
\hline & $(0.00213)$ & $(0.00121)$ & $(0.00174)$ \\
\hline \multirow[t]{2}{*}{ State population } & $0.61485^{\star \star \star}$ & $0.16403^{\star \star \star}$ & $0.45081^{\star \star \star}$ \\
\hline & $(0.00343)$ & $(0.00149)$ & $(0.00284)$ \\
\hline Observations & 64,163 & 64,163 & 64,163 \\
\hline
\end{tabular}

Note: Dependent variable is supply of immigrant entrepreneur (in 100,000s). All models control for demographic characteristics (age, marital status, education, number of children, and city residence status), state population (millions), state fixed effects, and year fixed effects. Robust standard errors are reported in parentheses.

SCHIP, State Children's Health Insurance Program.

${ }^{\star} p<0.10$.

${ }^{* *} p<0.05$.

$\star * \star p<0.01$ 
Table A6 Heterogeneity in the Impact of Immigrant Entrepreneurs across Races of Natives: Second Stage Estimates for Blacks

\begin{tabular}{|c|c|c|c|}
\hline Outcome & $\begin{array}{c}\text { Any self- } \\
\text { employment }\end{array}$ & $\begin{array}{c}\text { Incorporated } \\
\text { self-employment }\end{array}$ & $\begin{array}{l}\text { Unincorporated } \\
\text { self-employment }\end{array}$ \\
\hline \multirow[t]{2}{*}{ Immigrant entrepreneurs } & $0.09242^{\star}$ & 0.02171 & $0.12605^{\star}$ \\
\hline & $(0.05191)$ & $(0.08435)$ & $(0.06622)$ \\
\hline \multirow[t]{2}{*}{ Age } & $0.00142^{\star \star \star}$ & $0.00038^{\star \star \star}$ & $0.00105^{\star \star \star}$ \\
\hline & $(0.00008)$ & $(0.00004)$ & $(0.00007)$ \\
\hline \multirow[t]{2}{*}{ Female } & $-0.02960^{\star \star \star}$ & $-0.01345^{\star \star \star}$ & $-0.01614^{\star \star \star}$ \\
\hline & $(0.00177)$ & $(0.00098)$ & $(0.00150)$ \\
\hline \multirow[t]{2}{*}{ High school } & -0.00514 & $0.00246^{\star}$ & $-0.00735^{\star \star}$ \\
\hline & $(0.00342)$ & $(0.00132)$ & $(0.00320)$ \\
\hline \multirow[t]{2}{*}{ Some college } & -0.00147 & $0.00613^{\star \star \star}$ & $-0.00719^{\star \star}$ \\
\hline & $(0.00351)$ & $(0.00139)$ & $(0.00327)$ \\
\hline \multirow[t]{2}{*}{ College } & $0.00754^{\star}$ & $0.01698^{\star \star \star}$ & $-0.00899^{\star \star \star}$ \\
\hline & $(0.00391)$ & $(0.00191)$ & $(0.00348)$ \\
\hline \multirow[t]{2}{*}{ Advanced degree } & $0.01911^{\star \star \star}$ & $0.02570^{\star \star \star}$ & -0.00637 \\
\hline & $(0.00493)$ & $(0.00285)$ & $(0.00413)$ \\
\hline \multirow[t]{2}{*}{ Number of children } & $0.00388^{\star \star \star}$ & $0.00233^{\star \star \star}$ & $0.00152^{\star \star}$ \\
\hline & $(0.00074)$ & $(0.00042)$ & $(0.00063)$ \\
\hline \multirow[t]{2}{*}{ Lives in a city } & -0.00109 & -0.00188 & 0.00087 \\
\hline & $(0.00353)$ & $(0.00159)$ & $(0.00318)$ \\
\hline \multirow[t]{2}{*}{ State population } & $-0.05595^{\star}$ & -0.00293 & $-0.05658^{\star}$ \\
\hline & $(0.03182)$ & $(0.01364)$ & $(0.02985)$ \\
\hline Observations & 64,163 & 64,163 & 64,163 \\
\hline
\end{tabular}

Note: Dependent variable is binary indicator for being an entrepreneur. The supply of immigrant entrepreneurs is expressed in 100,000s. All models control for demographic characteristics (age, marital status, education, number of children, and city residence status), state population (millions), state fixed effects, and year fixed effects. Robust standard errors are reported in parentheses.

${ }^{*} p<0.10$.

${ }^{\star \star} p<0.05$.

${ }^{\star \star \star} p<0.01$. 
Table A7 Heterogeneity in the Impact of Immigrant Entrepreneurs across Races of Natives: First Stage Estimates for Whites

\begin{tabular}{|c|c|c|c|}
\hline Outcome & $\begin{array}{c}\text { Any self- } \\
\text { employment }\end{array}$ & $\begin{array}{l}\text { Incorporated } \\
\text { self-employment }\end{array}$ & $\begin{array}{l}\text { Unincorporated } \\
\text { self-employment }\end{array}$ \\
\hline \multirow[t]{2}{*}{ Generous SCHIP } & $0.02622^{\star \star \star}$ & $0.02212^{\star \star \star}$ & $0.00410^{\star \star \star}$ \\
\hline & $(0.00156)$ & $(0.00082)$ & $(0.00117)$ \\
\hline \multirow[t]{2}{*}{ Age } & -0.00001 & -0.00000 & -0.00000 \\
\hline & $(0.00002)$ & $(0.00001)$ & $(0.00002)$ \\
\hline \multirow[t]{2}{*}{ Female } & -0.00009 & 0.00002 & -0.00010 \\
\hline & $(0.00049)$ & $(0.00024)$ & $(0.00040)$ \\
\hline \multirow[t]{2}{*}{ High school } & 0.00018 & 0.00033 & -0.00015 \\
\hline & $(0.00123)$ & $(0.00063)$ & $(0.00102)$ \\
\hline \multirow[t]{2}{*}{ Some college } & -0.00002 & 0.00042 & -0.00044 \\
\hline & $(0.00124)$ & $(0.00063)$ & $(0.00104)$ \\
\hline \multirow[t]{2}{*}{ College degree } & 0.00166 & 0.00066 & 0.00100 \\
\hline & $(0.00127)$ & $(0.00065)$ & $(0.00106)$ \\
\hline \multirow[t]{2}{*}{ Advanced degree } & 0.00149 & 0.00086 & 0.00063 \\
\hline & $(0.00138)$ & $(0.00070)$ & $(0.00115)$ \\
\hline \multirow[t]{2}{*}{ Number of children } & -0.00028 & -0.00014 & -0.00015 \\
\hline & $(0.00022)$ & $(0.00011)$ & $(0.00018)$ \\
\hline \multirow[t]{2}{*}{ Lives in a city } & $0.00393^{\star \star \star}$ & $0.00184^{\star \star \star}$ & $0.00209^{\star \star \star}$ \\
\hline & $(0.00049)$ & $(0.00025)$ & $(0.00040)$ \\
\hline \multirow[t]{2}{*}{ State population } & $0.65092^{\star \star \star}$ & $0.17584^{\star \star \star}$ & $0.47509^{\star \star \star}$ \\
\hline & $(0.00144)$ & $(0.00062)$ & $(0.00122)$ \\
\hline Observations & 461,397 & 461,397 & 461,397 \\
\hline
\end{tabular}

Note: Dependent variable is supply of immigrant entrepreneur (in 100,000s). All models control for demographic characteristics (age, marital status, education, number of children, and city residence status), state population (millions), state fixed effects, and year fixed effects. Robust standard errors are reported in parentheses.

SCHIP, State Children's Health Insurance Program.

${ }^{\star} p<0.10$.

${ }^{* *} p<0.05$.

$\star * \star p<0.01$ 
Table A8 Heterogeneity in the Impact of Immigrant Entrepreneurs across Races of Natives: Second Stage Estimates for Whites

\begin{tabular}{|c|c|c|c|}
\hline Outcome & $\begin{array}{c}\text { Any self- } \\
\text { employment }\end{array}$ & $\begin{array}{c}\text { Incorporated } \\
\text { self-employment }\end{array}$ & $\begin{array}{l}\text { Unincorporated } \\
\text { self-employment }\end{array}$ \\
\hline \multirow[t]{2}{*}{ Immigrant entrepreneurs } & -0.04320 & 0.02171 & 0.51066 \\
\hline & $(0.10143)$ & (0.07292) & $(0.56062)$ \\
\hline \multirow[t]{2}{*}{ Age } & $0.00349^{\star \star \star}$ & $0.00157^{\star \star \star}$ & $0.00192^{\star \star \star}$ \\
\hline & $(0.00004)$ & (0.00003) & $(0.00004)$ \\
\hline \multirow[t]{2}{*}{ Female } & $-0.05136^{\star \star \star}$ & $-0.03497^{\star \star \star}$ & $-0.01634^{\star \star \star}$ \\
\hline & $(0.00091)$ & $(0.00057)$ & $(0.00078)$ \\
\hline \multirow[t]{2}{*}{ High school } & $-0.00803^{\star \star \star}$ & $0.01112^{\star \star \star}$ & $-0.01905^{\star \star \star}$ \\
\hline & $(0.00258)$ & $(0.00126)$ & (0.00239) \\
\hline \multirow[t]{2}{*}{ Some college } & -0.00276 & $0.01721^{\star \star \star}$ & $-0.01973^{\star \star \star}$ \\
\hline & $(0.00258)$ & $(0.00128)$ & $(0.00240)$ \\
\hline \multirow[t]{2}{*}{ College degree } & $0.00565^{\star \star}$ & $0.03003^{\star \star \star}$ & $-0.02478^{\star \star \star}$ \\
\hline & $(0.00263)$ & $(0.00135)$ & $(0.00246)$ \\
\hline \multirow[t]{2}{*}{ Advanced degree } & $0.01165^{\star \star \star}$ & $0.03379^{\star \star \star}$ & $-0.02236^{\star \star \star}$ \\
\hline & $(0.00284)$ & (0.00155) & $(0.00257)$ \\
\hline \multirow[t]{2}{*}{ Number of children } & $0.01590^{\star \star \star}$ & $0.00799^{\star \star \star}$ & $0.00797^{\star \star \star}$ \\
\hline & $(0.00044)$ & $(0.00028)$ & $(0.00038)$ \\
\hline \multirow[t]{2}{*}{ Lives in a city } & $0.02021^{\star \star \star}$ & $-0.00470^{\star \star \star}$ & $0.02409^{\star \star \star}$ \\
\hline & $(0.00136)$ & $(0.00076)$ & $(0.00163)$ \\
\hline \multirow[t]{2}{*}{ State population } & -0.02639 & 0.00969 & -0.24279 \\
\hline & $(0.06614)$ & $(0.01300)$ & $(0.26639)$ \\
\hline Observations & 461,397 & 461,397 & 461,397 \\
\hline
\end{tabular}

Note: Dependent variable is binary indicator for being an entrepreneur. The supply of immigrant entrepreneurs is expressed in 100,000s. All models control for demographic characteristics (age, marital status, education, number of children, and city residence status), state population (millions), state fixed effects, and year fixed effects. Robust standard errors are reported in parentheses.

${ }^{*} p<0.10$.

${ }^{\star \star} p<0.05$.

${ }^{\star \star \star} p<0.01$. 
Table A9 Heterogeneity in the Impact of Immigrant Entrepreneurs across Skill Levels of Natives: First Stage Estimates for Low Skilled

\begin{tabular}{|c|c|c|c|}
\hline Outcome & $\begin{array}{c}\text { Any self- } \\
\text { employment }\end{array}$ & $\begin{array}{c}\text { Incorporated } \\
\text { self-employment }\end{array}$ & $\begin{array}{l}\text { Unincorporated } \\
\text { self-employment }\end{array}$ \\
\hline \multirow[t]{2}{*}{ Generous SCHIP } & $0.04620^{\star \star \star}$ & $0.03038^{\star \star \star}$ & $0.01582^{\star \star \star}$ \\
\hline & $(0.00167)$ & $(0.00087)$ & $(0.00124)$ \\
\hline \multirow[t]{2}{*}{ Age } & -0.00003 & 0.00001 & -0.00003 \\
\hline & $(0.00003)$ & $(0.00001)$ & $(0.00002)$ \\
\hline \multirow[t]{2}{*}{ Female } & -0.00007 & 0.00021 & -0.00028 \\
\hline & $(0.00056)$ & $(0.00027)$ & $(0.00046)$ \\
\hline \multirow[t]{2}{*}{ High school } & -0.00047 & 0.00064 & -0.00111 \\
\hline & $(0.00110)$ & $(0.00054)$ & $(0.00091)$ \\
\hline \multirow[t]{2}{*}{ Some college } & -0.00085 & 0.00082 & $-0.00167^{\star}$ \\
\hline & $(0.00111)$ & $(0.00054)$ & $(0.00092)$ \\
\hline \multirow[t]{2}{*}{ White } & $-0.00437^{\star \star \star}$ & -0.00060 & $-0.00376^{\star \star \star}$ \\
\hline & $(0.00165)$ & $(0.00072)$ & $(0.00134)$ \\
\hline \multirow[t]{2}{*}{ Black } & $-0.00721^{\star \star \star}$ & $-0.00213^{\star \star}$ & $-0.00508^{\star \star \star}$ \\
\hline & $(0.00187)$ & $(0.00084)$ & $(0.00152)$ \\
\hline \multirow[t]{2}{*}{ Hispanic } & -0.00117 & 0.00056 & -0.00173 \\
\hline & $(0.00203)$ & $(0.00088)$ & $(0.00165)$ \\
\hline \multirow[t]{2}{*}{ Number of children } & -0.00000 & 0.00012 & -0.00012 \\
\hline & $(0.00025)$ & $(0.00012)$ & $(0.00021)$ \\
\hline \multirow[t]{2}{*}{ Lives in a city } & $0.00375^{\star \star \star}$ & $0.00168^{\star \star \star}$ & $0.00207^{\star \star \star}$ \\
\hline & $(0.00054)$ & $(0.00028)$ & $(0.00045)$ \\
\hline \multirow[t]{2}{*}{ State population } & $0.65169^{\star \star \star}$ & $0.17641^{\star \star \star}$ & $0.47528^{\star \star \star}$ \\
\hline & $(0.00139)$ & $(0.00060)$ & $(0.00117)$ \\
\hline Observations & 406,090 & 406,090 & 406,090 \\
\hline
\end{tabular}

Note: Dependent variable is supply of immigrant entrepreneur (in 100,000s). All models control for demographic characteristics (age, marital status, education, race, number of children, and city residence status), state population (millions), state fixed effects, and year fixed effects. Robust standard errors are reported in parentheses.

SCHIP, State Children's Health Insurance Program.

${ }^{*} p<0.10$.

${ }^{* *} p<0.05$.

${ }^{* \star *} p<0.01$. 
Table A10 Heterogeneity in the Impact of Immigrant Entrepreneurs across Skill Levels of Natives: Second Stage Estimates for Low Skilled

\begin{tabular}{|c|c|c|c|}
\hline Outcome & $\begin{array}{c}\text { Any self- } \\
\text { employment }\end{array}$ & $\begin{array}{c}\text { Incorporated } \\
\text { self-employment }\end{array}$ & $\begin{array}{l}\text { Unincorporated } \\
\text { self-employment }\end{array}$ \\
\hline \multirow[t]{2}{*}{ Immigrant entrepreneurs } & 0.03144 & -0.04661 & 0.18127 \\
\hline & $(0.05516)$ & $(0.04708)$ & $(0.13897)$ \\
\hline \multirow[t]{2}{*}{ Age } & $0.00264^{\star \star \star}$ & $0.00102^{\star \star \star}$ & $0.00162^{\star \star \star}$ \\
\hline & $(0.00004)$ & $(0.00002)$ & $(0.00004)$ \\
\hline \multirow[t]{2}{*}{ Female } & $-0.04654^{\star \star \star}$ & $-0.02342^{\star \star \star}$ & $-0.02307^{\star \star \star}$ \\
\hline & $(0.00090)$ & $(0.00052)$ & $(0.00077)$ \\
\hline \multirow[t]{2}{*}{ High school } & $-0.00584^{\star \star \star}$ & $0.00813^{\star \star \star}$ & $-0.01376^{\star \star \star}$ \\
\hline & $(0.00178)$ & $(0.00083)$ & $(0.00163)$ \\
\hline \multirow[t]{2}{*}{ Some college } & -0.00080 & $0.01370^{\star \star \star}$ & $-0.01419^{\star \star \star}$ \\
\hline & $(0.00179)$ & $(0.00086)$ & $(0.00164)$ \\
\hline \multirow[t]{2}{*}{ White } & $0.03208^{\star \star \star}$ & $0.01239^{\star \star \star}$ & $0.02021^{\star \star \star}$ \\
\hline & $(0.00253)$ & $(0.00129)$ & $(0.00230)$ \\
\hline \multirow[t]{2}{*}{ Black } & $-0.02104^{\star \star \star}$ & $-0.01112^{\star \star \star}$ & $-0.00932^{\star \star \star}$ \\
\hline & $(0.00272)$ & $(0.00137)$ & $(0.00250)$ \\
\hline \multirow[t]{2}{*}{ Hispanic } & $-0.01388^{\star \star \star}$ & $-0.00498^{\star \star \star}$ & $-0.00859^{\star \star \star}$ \\
\hline & $(0.00270)$ & $(0.00136)$ & $(0.00242)$ \\
\hline \multirow[t]{2}{*}{ Number of children } & $0.01184^{\star \star \star}$ & $0.00497^{\star \star \star}$ & $0.00690^{\star \star \star}$ \\
\hline & $(0.00042)$ & $(0.00024)$ & $(0.00036)$ \\
\hline \multirow[t]{2}{*}{ Lives in a city } & $0.02034^{\star \star \star}$ & $-0.00425^{\star \star \star}$ & $0.02441^{\star \star \star}$ \\
\hline & $(0.00132)$ & $(0.00070)$ & $(0.00119)$ \\
\hline \multirow[t]{2}{*}{ State population } & -0.01453 & 0.00996 & -0.08193 \\
\hline & $(0.03602)$ & $(0.00842)$ & $(0.06607)$ \\
\hline Observations & 406,090 & 406,090 & 406,090 \\
\hline
\end{tabular}

Note: Dependent variable is binary indicator for being an entrepreneur. The supply of immigrant entrepreneurs is expressed in 100,000s. All models control for demographic characteristics (age, marital status, education, race, number of children, and city residence status), state population (millions), state fixed effects, and year fixed effects. Robust standard errors are reported in parentheses.

${ }^{*} p<0.10$.

${ }^{* *} p<0.05$.

${ }^{\star \star \star} p<0.01$ 
Table A11 Heterogeneity in the Impact of Immigrant Entrepreneurs across Skill Levels of Natives: First Stage Estimates for High Skilled

\begin{tabular}{|c|c|c|c|}
\hline Outcome & $\begin{array}{l}\text { Any self- } \\
\text { employment }\end{array}$ & $\begin{array}{l}\text { Incorporated } \\
\text { self-employment }\end{array}$ & $\begin{array}{l}\text { Unincorporated } \\
\text { self-employment }\end{array}$ \\
\hline \multirow[t]{2}{*}{ Generous SCHIP } & $0.04370^{\star \star \star}$ & $0.02993^{\star \star \star}$ & $0.01377^{\star \star \star}$ \\
\hline & $(0.00251)$ & $(0.00130)$ & $(0.00185)$ \\
\hline \multirow[t]{2}{*}{ Age } & 0.00000 & -0.00001 & 0.00001 \\
\hline & $(0.00004)$ & $(0.00002)$ & $(0.00003)$ \\
\hline \multirow[t]{2}{*}{ Female } & 0.00047 & -0.00023 & 0.00070 \\
\hline & $(0.00082)$ & $(0.00039)$ & $(0.00067)$ \\
\hline \multirow[t]{2}{*}{ College degree } & -0.00021 & -0.00019 & -0.00002 \\
\hline & $(0.00088)$ & $(0.00042)$ & $(0.00072)$ \\
\hline \multirow[t]{2}{*}{ White } & $-0.00965^{\star \star \star}$ & $-0.00237^{\star}$ & $-0.00728^{\star \star \star}$ \\
\hline & $(0.00298)$ & $(0.00128)$ & $(0.00247)$ \\
\hline \multirow[t]{2}{*}{ Black } & $-0.01125^{\star \star \star}$ & -0.00238 & $-0.00887^{\star \star \star}$ \\
\hline & $(0.00336)$ & $(0.00148)$ & $(0.00277)$ \\
\hline \multirow[t]{2}{*}{ Hispanic } & 0.00012 & 0.00142 & -0.00130 \\
\hline & $(0.00385)$ & $(0.00164)$ & $(0.00320)$ \\
\hline \multirow[t]{2}{*}{ Number of children } & $-0.00093^{\star \star}$ & $-0.00049^{\star \star \star}$ & -0.00044 \\
\hline & $(0.00036)$ & $(0.00017)$ & $(0.00030)$ \\
\hline \multirow[t]{2}{*}{ Lives in a city } & $0.00487^{\star \star \star}$ & $0.00240^{\star \star \star}$ & $0.00247^{\star \star \star}$ \\
\hline & $(0.00090)$ & $(0.00045)$ & $(0.00074)$ \\
\hline \multirow[t]{2}{*}{ State population } & $0.68288^{\star \star \star}$ & $0.18323^{\star \star \star}$ & $0.49965^{\star \star \star}$ \\
\hline & $(0.00205)$ & $(0.00087)$ & $(0.00176)$ \\
\hline Observations & 203,275 & 203,275 & 203,275 \\
\hline
\end{tabular}

Note: Dependent variable is supply of immigrant entrepreneur (in 100,000s). All models control for demographic characteristics (age, marital status, education, race, number of children, and city residence status), state population (millions), state fixed effects, and year fixed effects. Robust standard errors are reported in parentheses.

SCHIP, State Children's Health Insurance Program.

${ }^{\star} p<0.10$.

${ }^{* *} p<0.05$.

$\star * \star p<0.01$ 
Table A12 Heterogeneity in the Impact of Immigrant Entrepreneurs across Skill Levels of Natives: Second Stage Estimates for High Skilled

\begin{tabular}{|c|c|c|c|}
\hline Outcome & $\begin{array}{c}\text { Any self- } \\
\text { employment }\end{array}$ & $\begin{array}{c}\text { Incorporated } \\
\text { self-employment }\end{array}$ & $\begin{array}{l}\text { Unincorporated } \\
\text { self-employment }\end{array}$ \\
\hline \multirow[t]{2}{*}{ Immigrant entrepreneurs } & 0.03144 & -0.04661 & 0.18127 \\
\hline & $(0.05516)$ & $(0.04708)$ & $(0.13897)$ \\
\hline \multirow[t]{2}{*}{ Age } & $0.00412^{\star \star \star}$ & $0.00189^{\star \star \star}$ & $0.00223^{\star \star \star}$ \\
\hline & $(0.00007)$ & $(0.00004)$ & $(0.00005)$ \\
\hline \multirow[t]{2}{*}{ Female } & $-0.04593^{\star \star \star}$ & $-0.04148^{\star \star \star}$ & $-0.00449^{\star \star \star}$ \\
\hline & $(0.00138)$ & $(0.00093)$ & $(0.00109)$ \\
\hline \multirow[t]{2}{*}{ College degree } & $-0.00477^{\star \star \star}$ & $-0.00353^{\star \star \star}$ & -0.00125 \\
\hline & $(0.00155)$ & $(0.00108)$ & $(0.00119)$ \\
\hline \multirow[t]{2}{*}{ White } & $0.01376^{\star \star \star}$ & $0.00908^{\star \star \star}$ & 0.00503 \\
\hline & $(0.00394)$ & $(0.00245)$ & $(0.00359)$ \\
\hline \multirow[t]{2}{*}{ Black } & $-0.03556^{\star \star \star}$ & $-0.01289^{\star \star \star}$ & $-0.02224^{\star \star \star}$ \\
\hline & $(0.00437)$ & $(0.00273)$ & $(0.00404)$ \\
\hline \multirow[t]{2}{*}{ Hispanic } & $-0.02256^{\star \star \star}$ & $-0.00520^{\star}$ & $-0.01726^{\star \star \star}$ \\
\hline & $(0.00446)$ & $(0.00289)$ & $(0.00361)$ \\
\hline \multirow[t]{2}{*}{ Number of children } & $0.01358^{\star \star \star}$ & $0.00855^{\star \star \star}$ & $0.00504^{\star \star \star}$ \\
\hline & $(0.00068)$ & $(0.00048)$ & $(0.00052)$ \\
\hline \multirow[t]{2}{*}{ Lives in a city } & $0.00794^{\star \star \star}$ & $-0.00501^{\star \star \star}$ & $0.01288^{\star \star \star}$ \\
\hline & $(0.00244)$ & $(0.00159)$ & $(0.00202)$ \\
\hline \multirow[t]{2}{*}{ State population } & 0.01691 & 0.01176 & -0.01816 \\
\hline & $(0.06453)$ & $(0.01675)$ & $(0.12021)$ \\
\hline Observations & 203,275 & 203,275 & 203,275 \\
\hline
\end{tabular}

Note: Dependent variable is binary indicator for being an entrepreneur. The supply of immigrant entrepreneurs is expressed in 100,000s. All models control for demographic characteristics (age, marital status, education, race, number of children, and city residence status), state population (millions), state fixed effects, and year fixed effects. Robust standard errors are reported in parentheses.

${ }^{*} p<0.10$.

${ }^{\star \star} p<0.05$.

$\star \star \star x<0.01$. 
Table A13 Heterogeneity in the Impact of Immigrant Entrepreneurs across Natives by Parents' Origin: TSLS Estimates

\begin{tabular}{lccc}
\hline Outcome & $\begin{array}{c}\text { Any self- } \\
\text { employment }\end{array}$ & $\begin{array}{c}\text { Incorporated } \\
\text { self-employment }\end{array}$ & $\begin{array}{c}\text { Unincorporated } \\
\text { self-employment }\end{array}$ \\
\hline $\begin{array}{l}\text { At least one foreign born parent } \\
\text { Entrepreneurial propensity }\end{array}$ & 0.0935 & 0.0357 & 0.0578 \\
of natives: & & & \\
Immigrant entrepreneurs & -0.1659 & -0.1791 & -0.1510 \\
& $(0.1109)$ & $(0.1286)$ & $0.1945)$ \\
First stage F stat & 139.94 & 144.049 & 369.79 \\
Observations & 64,475 & 64,475 & 64,475 \\
\hline No foreign born parents & & & \\
Entrepreneurial propensity & 0.0997 & 0.0350 & 0.0647 \\
of natives: & & & \\
Immigrant entrepreneurs & 0.0369 & -0.0349 & 0.1834 \\
& $(0.0514)$ & $(0.0454)$ & $0.1321)$ \\
First stage F stat & 984.07 & 1622.47 & 194.04 \\
Observations & 544,890 & 544,890 & 544,890 \\
\hline
\end{tabular}

Note: Data span 1997-2008 from the ASEC of the CPS. Dependent variable is binary indicator for being an entrepreneur. The supply of immigrant entrepreneurs is expressed in 100,000 s. All models control for demographic characteristics (age, marital status, education, race, number of children, and city residence status), state population (millions), state fixed effects, and year fixed effects. Robust standard errors are reported in parentheses. ASEC, Annual Social and Economic Supplement; CPS, Current Population Survey; TSLS, two stage least squares.

${ }^{\star} p<0.10$.

${ }^{* \star} p<0.05$.

${ }^{\star \star *} p<0.01$. 
Table A14 Results from Nonlinear Models

\begin{tabular}{lccc}
\hline Outcome & $\begin{array}{c}\text { Any self- } \\
\text { employment }\end{array}$ & $\begin{array}{c}\text { Incorporated } \\
\text { self-employment }\end{array}$ & $\begin{array}{c}\text { Unincorporated } \\
\text { self-employment }\end{array}$ \\
\hline $\begin{array}{l}\text { Entrepreneurial propensity } \\
\text { of natives: }\end{array}$ & 0.0950 & 0.0345 & 0.0606 \\
\hline Probit & $0.0064^{\star \star \star}$ & $0.0068^{\star \star \star}$ & $0.0035^{\star}$ \\
Immigrant entrepreneurs & $(0.0019)$ & $(0.0023)$ & $(0.0019)$ \\
Observations & 609,365 & 609,365 & 609,365 \\
\hline IV probit & & & \\
Second stage: & & & 0.0037 \\
Immigrant entrepreneurs & 0.0067 & 0.0083 & $(0.1116)$ \\
& $(0.0475)$ & $(0.0459)$ & 1374.92 \\
First stage F-stat & 2101.30 & 2697.76 & 609,365 \\
Observations & 609,365 & 609,365 & \\
\hline
\end{tabular}

Note: Estimates are marginal effects calculated at means. Dependent variable is binary indicator for being an entrepreneur. The supply of immigrant entrepreneurs is expressed in 100,000s. All models control for demographic characteristics (age, marital status, education, race, number of children, and city residence status), state population (millions), state fixed effects, and year fixed effects. Robust standard errors are reported in parentheses.

${ }^{\star} p<0.10$.

${ }^{\star \star} p<0.05$.

${ }^{\star \star \star} p<0.01$.

Table A15 Results using Immigrant Entrepreneurship Rate as the Key Explanatory Variable

\begin{tabular}{lccc}
\hline Outcome & $\begin{array}{c}\text { Any self- } \\
\text { employment }\end{array}$ & $\begin{array}{c}\text { Incorporated } \\
\text { self-employment }\end{array}$ & $\begin{array}{c}\text { Unincorporated } \\
\text { self-employment }\end{array}$ \\
\hline $\begin{array}{l}\text { Entrepreneurial propensity of } \\
\text { natives }\end{array}$ & 0.0950 & 0.0345 & 0.0606 \\
\hline LPM & & & \\
Immigrant entrepreneurship & $0.00042^{\star *}$ & 0.00027 & 0.00018 \\
rate & $(0.00020)$ & $(0.00027)$ & $(0.00019)$ \\
Observations & 609,365 & 609,365 & 609,365 \\
\hline TSLS & & & \\
Second stage & & & 0.0089 \\
Immigrant entrepreneurship & 0.0029 & 0.0299 & $(0.0082)$ \\
rate & $(0.0125)$ & $(0.0266)$ & 174.76 \\
First stage F-stat & 92.93 & 25.20 & 609,365 \\
Observations & 609,365 & 609,365 & \\
\hline
\end{tabular}

Note: Dependent variable is binary indicator for being an entrepreneur. Immigrant entrepreneurship rate is the percentage of immigrants that report as being self-employed. All models control for demographic characteristics (age, marital status, education, race, number of children, and city residence status), state population (millions), state fixed effects, and year fixed effects.

LPM, linear probability model; TSLS, two stage least squares.

${ }^{*} p<0.10$.

${ }^{\star \star} p<0.05$.

${ }^{\star \star \star} p<0.01$. 
Table A16 Effect of SCHIP on Entry of Immigrants into Entrepreneurship

\begin{tabular}{lcc}
\hline & $\begin{array}{c}\text { Entry into entrepreneurship } \\
\text { (measured as a proportion) }\end{array}$ & $\begin{array}{c}\text { Entry into entrepreneur- } \\
\text { ship (measured as count) }\end{array}$ \\
\hline Sample mean/proportion & 0.007 & $1,324.39$ \\
SCHIP & $0.0090^{\star \star \star}$ & $0.0156^{\star \star \star}$ \\
& $(0.0001)$ & $(0.0012)$ \\
Observations & 609,365 & 609,365 \\
\hline
\end{tabular}

Note: Estimates represent the effect of generous SCHIP on annual entry of immigrants into entrepreneurship. All models control for demographic characteristics (age, marital status, education, race, number of children, and city residence status), state population (millions), state fixed effects, and year fixed effects. Robust standard errors are reported in parentheses. SCHIP, State Children's Health Insurance Program.

${ }^{\star} p<0.10$.

${ }^{\star *} p<0.05$.

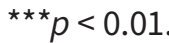

Table A17 Results with Separate Controls for Immigrant and Native Population

\begin{tabular}{lccc}
\hline Outcome & $\begin{array}{c}\text { Any self- } \\
\text { employment }\end{array}$ & $\begin{array}{c}\text { Incorporated } \\
\text { self-employment }\end{array}$ & $\begin{array}{c}\text { Unincorporated } \\
\text { self-employment }\end{array}$ \\
\hline Immigrant entrepreneurs & 0.01247 & 0.5644 & -0.0130 \\
First stage F-stat & $(0.0258)$ & $(0.3684)$ & $(0.0225)$ \\
Observations & $7,012.38$ & 72.25 & $8,873.64$ \\
\hline
\end{tabular}

Note: Dependent variable is binary indicator for being an entrepreneur. The supply of immigrant entrepreneurs is expressed in 100,000s. All models control for demographic characteristics (age, marital status, education, race, number of children, and city residence status), state immigrant population (millions), state native population (millions), state fixed effects, and year fixed effects. Robust standard errors are reported in parentheses.

${ }^{*} p<0.10$.

${ }^{\star \star} p<0.05$.

${ }^{\star \star *} p<0.01$. 
Figure A1 Event Study for the Impact of SCHIP on Immigrant Inflows to Generous States.

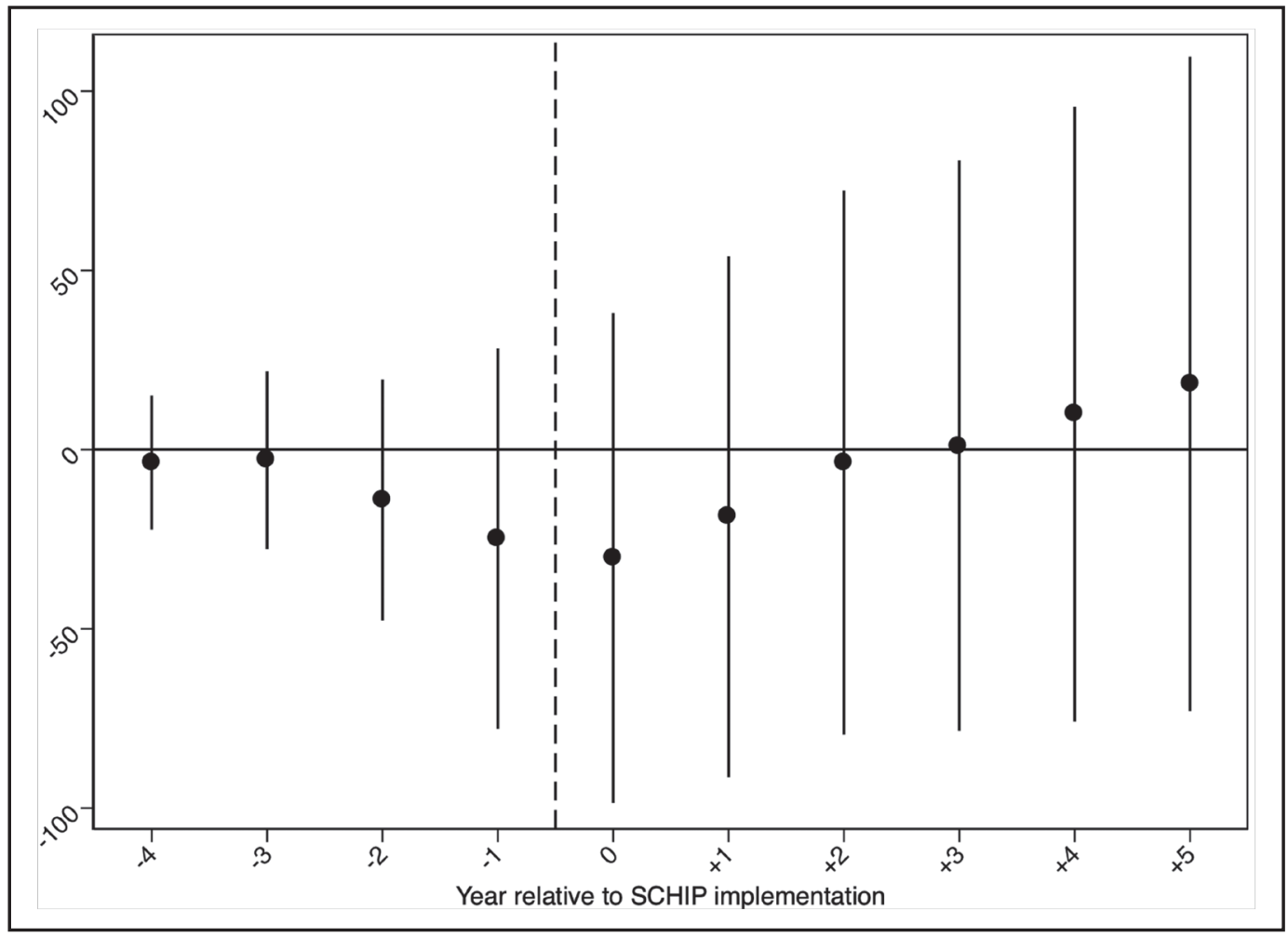

Notes: Data span 1994-2016 from the ASEC of the CPS. Estimates with 95\% confidential interval are for the impact of generous SCHIP on annual inflows of immigrants to generous states. Observations before 5 years of SCHIP are added to " -5 " bin and those beyond 5 years post SCHIP are included in the " +5 " bin. Then, " -5 " is dropped as the omitted category. All additional controls included in the baseline regression are retained. See text for further details. ASEC, Annual Social and Economic Supplement; CPS, Current Population Survey; SCHIP, State Children's Health Insurance Program. 